\title{
Synthesis, Spectroscopic, and Biological Studies on New Zirconium(IV) Porphyrins with Axial Ligand
}

\author{
Gauri D. Bajju, ${ }^{1}$ Gita Devi, ${ }^{1}$ Sapna Katoch, ${ }^{1}$ Madhulika Bhagat, ${ }^{2}$ \\ Deepmala, ${ }^{1}$ Ashu, ${ }^{1}$ Sujata Kundan, ${ }^{1}$ and Sunil Kumar Anand ${ }^{1}$ \\ ${ }^{1}$ P.G. Department of Chemistry, University of Jammu, Jammu, Jammu and Kashmir 180006, India \\ ${ }^{2}$ School of Biotechnology, University of Jammu, Jammu, Jammu and Kashmir 180006, India \\ Correspondence should be addressed to Gauri D. Bajju; gauribajju@gmail.com
}

Received 25 April 2013; Accepted 27 June 2013

Academic Editor: Konstantinos Tsipis

Copyright (C) 2013 Gauri D. Bajju et al. This is an open access article distributed under the Creative Commons Attribution License, which permits unrestricted use, distribution, and reproduction in any medium, provided the original work is properly cited.

A series of parasubstituted tetraphenylporphyrin zirconium(IV) salicylate complexes (SA/5-SSAZr(IV)RTPP, $\mathrm{R}=\mathrm{p}-\mathrm{H}, \mathrm{p}-\mathrm{CH}_{3}$, $\mathrm{p}-\mathrm{NO}_{2}, \mathrm{p}-\mathrm{Cl}, \mathrm{SA}=$ salicylate, and 5-SSA = 5-sulfosalicylate) have been synthesized, and the spectral properties of free base porphyrins, their corresponding metallated, and axially ligated zirconium(IV) porphyrin compounds were compared with each other. A detailed analysis of ultraviolet-visible (UV-vis), proton nulcear magnetic resonance $\left({ }^{1} \mathrm{H}\right.$ NMR) spectroscopy, infrared (IR) spectroscopy, and elemental analysis suggested the transformation from free base porphyrins to zirconium(IV) porphyrins. The ability of the metal in this complex for extra coordination of solvent molecules was confirmed by ESI-MS spectra. Besides the fluorescence, cyclic voltammetry, and thermogravimetric studies, the complexes were also screened for antimicrobial and anticancer activities. Among all the complexes, 5-SSAZr $\left(\mathrm{p}-\mathrm{NO}_{2} \mathrm{TPP}\right)$ shows high antibacterial activity.

\section{Introduction}

Synthesis and functionalization of porphyrins [1] have long been of great interest in the chemistry community because of the vast potentials and demands for porphyrin derivatives in diverse fields, such as materials $[2,3]$, supramolecular chemistry $[4,5]$, biomimetic models $[6]$, catalysis $[7,8]$, photodynamic therapy [9], and ionophores [10]. Porphyrins were reported to exhibit a variety of biological activities. This is due to the fact that natural and synthetic porphyrins have relatively low toxicity in vitro and in vivo and they possess antitumor $[11,12]$ and antioxidant effects $[13,14]$ and have a good potential for metal ions complexation. The ability for numerous chemical modifications and the large number of different mechanisms by which porphyrins affect microbial and viral pathogens place porphyrins into a group of compounds with an outstanding potential for discovery of novel agents, procedures, and materials active against pathogenic microorganisms [15]. Metalloporphyrins are the basis of new antifungal, antiparasitic, and anticancer drugs because modification of the porphyrin periphery confers qualitatively a new spectrum of activities to metalloporphyrins $[16,17]$. It has been reported that metal complexation alters the various physiological properties, especially the cytotoxic and antitumor activities, of many naturally occurring compounds. Zirconium(IV) porphyrins have gained attention from global researchers due to the peculiar characteristics of this class of compounds. To the best of our knowledge, the chemistry of zirconium(IV) porphyrinates remains underdeveloped, being limited to OEP and TPP, with a small variety of derivatives with different anions to balance the remaining +2 charge and ligands to satisfy the 7-8 coordination sphere. The metal ion in these complexes is oxophilic [18]; thus, it may show preference for carboxylate and other oxygen-bearing anionic ligands. A lot of work is reported on the spectral, electrochemical, and biological properties of zirconium and hafnium phthalocyanines with different outplaned organic ligands [19-22], but comparatively less work has been done on zirconium(IV) porphyrin complexes with carboxylate as axial ligand which are expected to be biomedically relevant complexes. Salicylic acid and its derivatives are biologically important molecules, and in view of the interesting results obtained from zirconium(IV) phthalocyanines with various out-of-plane ligands, it is considered worthwhile to make 
a study of axially substituted zirconium(IV) porphyrin with salicylic acid and its derivatives. We believe that these novel compounds will be fundamental substances for potential applications in the future. With this objective, we aimed at the synthesis, spectroscopic characterization, and biological studies on axially substituted zirconium(IV) porphyrins with salicylic acid and 5-sulfosalicylic acid as axial ligands.

\section{Experimental}

2.1. Materials and Instruments. All the chemicals were of analytical grade and used as received unless otherwise noted. Pyrrole was distilled over potassium hydroxide pellets under vacuum prior to use. All the organic solvents that were used for the synthesis and for chromatographic separations were dried before use. (TBA) $\mathrm{PF}_{6}$ was recrystallized twice from EtOAc and dried in vacuo prior to use. Elementary analyses $(\mathrm{C}, \mathrm{H}, \mathrm{N}$, and $\mathrm{S}$ ) were obtained on a Vario EL III and CHNS-932 Leco Elemental Analyzer. UV-vis spectra were recorded on a T90+ UV/VIS spectrophotometer in the range $350-700 \mathrm{~nm}$. The oscillator strength $(f)$ of the transitions in absorption spectra were calculated from the expression

$$
f=4.33 \times 10^{-9} \varepsilon \Delta \nu_{1 / 2},
$$

where $\varepsilon$ is the molar absorption coefficient in $\mathrm{dm}^{3} \mathrm{~mol}^{-1} \mathrm{~cm}^{-1}$ and $\Delta v_{1 / 2}$ is the full width at half maximum in $\mathrm{cm}^{-1}$. Infrared spectra were recorded on a Perkin Elmer-spectrum 400 FTIR spectrophotometer using $\mathrm{KBr}$ pellets in the range of 4000$400 \mathrm{~cm}^{-1}$. The ${ }^{1} \mathrm{H}$ NMR spectra were recorded on a Bruker Avance II $500(500 \mathrm{MHz})$ using tetramethylsilane as internal standard and $\mathrm{CDCl}_{3}$ as solvent. TGA and DTA were recorded on Linseis STA PT-100 thermometer using around $21.87 \mathrm{mg}$ of dry samples at the heating rate of $10^{\circ} \mathrm{C} / \mathrm{min}$ in an air atmosphere. The cyclic voltammetry measurements were carried out by an Autolab computer-controlled electrochemical measurement system equipped with a potentiostat. A threeelectrode system comprised a gold working electrode, a $\mathrm{Pt}$ wire counter electrode, and a saturated $\mathrm{Ag} / \mathrm{AgCl}$ in $\mathrm{KCl}$ as reference electrode. A $0.1 \mathrm{M}$ solution of n-tetrabutylammonium hexafluorophosphate, (TBA) $\mathrm{PF}_{6}$ in freshly distilled $\mathrm{CH}_{2} \mathrm{Cl}_{2}$, was used as a supporting electrolyte during the electrochemical experiments. The scan rate was $20 \mathrm{mV} / \mathrm{s}$ and the range was $-0.2-0.2 \mathrm{mV}$. The concentration of the porphyrins was $10^{-6} \mathrm{M}$. The solutions were purged with oxygen-free nitrogen gas prior to measurements, and all measurements were made at room temperature. Fluorescence measurements were performed on Synergy MX Biotek Multimode Reader. The porphyrins solution prepared in $\mathrm{CH}_{2} \mathrm{Cl}_{2}$ was $10^{-6} \mathrm{M}$.

\subsection{Biological Studies}

2.2.1. Antibacterial Studies. Qualitative analysis for screening of antibacterial activity was carried out by Agar welldiffusion method [23] with modifications. The compound was tested against two Gram positive bacteria (Bacillus subtilis MTCC2389 and Staphylococcus aureus MTCC7443) and three Gram negative bacteria (Micrococcus luteus MTCC4821, Escherichia coli MTCC2127, and Pseudomonas fluorescens MTCC4828). $20 \mathrm{~mL}$ of sterilized nutrient agar was inoculated with $100 \mathrm{~mL}$ of bacterial suspension $\left(10^{8} \mathrm{CFU} / \mathrm{mL}\right)$ and then poured onto sterilized Petri plate. The agar plate was left to solidify at room temperature. A well of $6 \mathrm{~mm}$ was aseptically bored into the agar plate. Then, $20 \mathrm{~mL}$ of the complexes (diluted with DMSO, 1:1) was added in each well. Chloramphenicol $(10 \mu \mathrm{g})$ was used as a positive reference to determine the sensitivity of bacteria. The plates were kept at $4^{\circ} \mathrm{C}$ for 2 hours to allow the dispersal and then incubated at $37^{\circ} \mathrm{C}$ for 24 hours.

\subsubsection{In Vitro Cytotoxicity against Human Cancer Cell Lines}

Cell Lines and Cell Cultures. The human prostrate (PC-3), lung (A-549), and acute lymphoblastic leukemia (THP-1) cell lines were grown and maintained in RPMI-1640 medium, $\mathrm{pH}$ 7.4, whereas DMEM was used for breast (MCF-7). The media were supplemented with FCS (10\%), penicillin (100 units $/ \mathrm{mL})$, streptomycin $(100 \mu \mathrm{g} / \mathrm{mL})$, and glutamine $(2 \mathrm{mM})$, and cells were grown in $\mathrm{CO}_{2}$ incubator (Heraeus, $\mathrm{GmbH}$, Germany) at $37^{\circ} \mathrm{C}$ with $90 \%$ humidity and $5 \% \mathrm{CO}_{2}$. Cells were treated with samples dissolved in DMSO while the untreated control cultures received only the vehicle (DMSO, $<0.2 \%)$.

Cytotoxicity Assay. In vitro cytotoxicity against human cancer cell lines was determined using sulforhodamine B dye assay $[24,25]$. Both test samples stock solutions were prepared in DMSO.

\subsection{Synthesis of Axially Ligated Zirconium(IV) Porphyrins Complexes}

2.3.1. Synthesis of Macrocycles. The metal free-base mesotetraphenylporphyrin (TPP) and its parasubstituted derivative (RTPP, $\mathrm{R}=\mathrm{p}-\mathrm{CH}_{3}, \mathrm{p}-\mathrm{NO}_{2}, \mathrm{p}-\mathrm{Cl}$ ) were synthesized by the direct condensation of pyrrole with substituted benzaldehydes according to the documented procedure [26]. The purified porphyrin complexes were obtained in yields of less than $25 \%$.

\subsubsection{Synthesis of Dichloro(5,10,15,20-tetraarylporphinato)zir-} conium(IV), $\quad \mathrm{Cl}_{2} \mathrm{Zr}(\mathrm{RTPP})$. Dichloro(5,10,15,20-tetraphenylporphinato)zirconium(IV), $\mathrm{Cl}_{2} \mathrm{Zr}(\mathrm{RTPP}) \mathrm{s}$ were obtained by the reaction of mesotetraphenylporphyrin and its parasubstituted derivatives, RTPP $\left(\mathrm{R}=\mathrm{p}-\mathrm{H}, \mathrm{p}-\mathrm{CH}_{3}, \mathrm{p}-\mathrm{NO}_{2}\right.$, $\mathrm{p}-\mathrm{Cl}$ ) with zirconium(IV)chloride by benzonitrile method [27]. RTPP (0.41 mmol) was boiled with $\mathrm{ZrCl}_{4}$ (2.64 mmol) in $15 \mathrm{~mL}$ of benzonitrile at reflux for $1-3$ hours. The reaction course was monitored by absorption spectra of the reaction mixture. The refluxing was stopped when in the electron absorption spectra of the reaction mixture disappeared the absorption bands of RTPP. The complex was isolated in the solid form after distilling benzonitrile off in a vacuum. Then the saturated solution of the complex in chloroform was subjected to chromatography on basic $\mathrm{Al}_{2} \mathrm{O}_{3}$ using $\mathrm{CHCl}_{3}$ as eluent. After chromatography, the solution of the zirconium(IV) complex was treated additionally with gaseous $\mathrm{HCl}$. The purified dichlorozirconium(IV) porphyrin complexes were obtained in yields of around 30\%. 
(1) Dichloro(5,10,15,20-tetraphenylporphinato)zirconium(IV), $\mathrm{Cl}_{2} \mathrm{ZrTPP}$. Red-violet. Anal. Calcd. for $\mathrm{C}_{44} \mathrm{H}_{28} \mathrm{Cl}_{2} \mathrm{~N}_{4} \mathrm{Zr}(\%)$ : C 68.20, H 3.64, N 7.23. Found: C 68.32, H 3.66, N 7.24. UVvis spectra $\left(\mathrm{CHCl}_{3}\right) \lambda_{\text {max }}: 407 \mathrm{~nm}$ (Soret band), $541 \mathrm{~nm}(\mathrm{Q}-$ band). IR (KBr) $\nu_{\max }: 485 \mathrm{~cm}^{-1}\left(\nu_{\mathrm{Zr}-\mathrm{N}}\right) .{ }^{1} \mathrm{H}$ NMR $(500 \mathrm{MHz}$, $\mathrm{CDCl}_{3}$ ): 8.87 (8H, s, pyrrole), 8.32 (4H, d, o-phenyl), 8.04 (4H, d, o-phenyl), 7.64 (12H, s, m-phenyl, p-phenyl).

(2) Dichloro(meso-tetra(p-methylphenyl)porphyrinato)zirconium(IV), $\mathrm{Cl}_{2} \mathrm{Zr}\left(p-\mathrm{CH}_{3} \mathrm{TPP}\right)$. Yellowish brown solid. Anal. Calcd. for $\mathrm{C}_{48} \mathrm{H}_{36} \mathrm{Cl}_{2} \mathrm{~N}_{4} \mathrm{Zr}(\%)$ : C 69.38, $\mathrm{H}$ 4.37, N 6.74 . Found: C 69.42, H 4.41, N 6.79. UV-vis spectra $\left(\mathrm{CHCl}_{3}\right) \lambda_{\text {max }}$ : $409 \mathrm{~nm}$ (Soret band), $540 \mathrm{~nm}$ (Q-band). IR (KBr) $\nu_{\max }$ : $508 \mathrm{~cm}^{-1}\left(\nu_{\mathrm{Zr}-\mathrm{N}}\right) .{ }^{1} \mathrm{H}$ NMR $\left(500 \mathrm{MHz}, \mathrm{CDCl}_{3}\right): 8.80(8 \mathrm{H}, \mathrm{s}$, pyrrole), 8.28 (4H, s, o-phenyl), $8.00(4 \mathrm{H}, \mathrm{s}, \mathrm{o}$-phenyl), 7.65 (8H, s, m-phenyl), $2.70\left(\mathrm{~s}, 12 \mathrm{H}, \mathrm{p}-\mathrm{CH}_{3}\right)$.

(3) Dichloro(meso-tetra(p-chlorophenyl)porphyrinato)zirconium(IV), $\mathrm{Cl}_{2} \mathrm{Zr}$ (p-ClTPP). Red-violet solid. Anal. Calcd. for $\mathrm{C}_{44} \mathrm{H}_{24} \mathrm{Cl}_{6} \mathrm{~N}_{4} \mathrm{Zr}(\%)$ : C 57.91, H 2.65, N 6.14. Found: C 58.03, $\mathrm{H}$ 2.68, N 6.23. UV-Vis spectra $\left(\mathrm{CHCl}_{3}\right) \lambda_{\text {max }}: 416 \mathrm{~nm}$ (Soret band), $541 \mathrm{~nm}$ (Q-band). IR (KBr) $\nu_{\max }: 485 \mathrm{~cm}^{-1}\left(\nu_{\mathrm{Zr}-\mathrm{N}}\right) .{ }^{1} \mathrm{H}$ NMR (500 MHz, $\left.\mathrm{CDCl}_{3}\right): 8.97(8 \mathrm{H}, \mathrm{s}$, pyrrole), $8.33(4 \mathrm{H}, \mathrm{d}$, o-phenyl), 8.13 (4H, s, o-phenyl), 7.59 (8H, s, m-phenyl).

(4) Dichloro(meso-tetra(p-nitrophenyl)porphyrinato)zirconium(IV), $\mathrm{Cl}_{2} \mathrm{Zr}\left(p-\mathrm{NO}_{2} \mathrm{TPP}\right)$. Reddish brown solid. Anal. Calcd. for $\mathrm{C}_{44} \mathrm{H}_{24} \mathrm{Cl}_{2} \mathrm{~N}_{8} \mathrm{O}_{8} \mathrm{Zr}(\%)$ : C 55.35, H 2.53, N 11.74. Found: C 55.42, H 2.56, N 11.63. UV-vis spectra $\left(\mathrm{CHCl}_{3}\right) \lambda_{\max }$ : $414 \mathrm{~nm}$ (Soret band), $543 \mathrm{~nm}$ (Q-band). IR (KBr) $\nu_{\max }$ : $482 \mathrm{~cm}^{-1}\left(\nu_{\mathrm{Zr}-\mathrm{N}}\right) .{ }^{1} \mathrm{H}$ NMR $\left(500 \mathrm{MHz}, \mathrm{CDCl}_{3}\right): 9.05(8 \mathrm{H}$, s, pyrrole), $8.42(4 \mathrm{H}, \mathrm{s}$, o-phenyl), $8.04(4 \mathrm{H}, \mathrm{s}, \mathrm{o}-$ phenyl), 7.65(8H, s, m-phenyl).

2.3.3. Synthesis of Axially Ligated $\operatorname{Zr}(I V)$ Porphyrins: $S A Z r(R T P P)$ and 5-SSAZr(RTPP). $\mathrm{Cl}_{2} \mathrm{Zr}$ (RTPP) (0.15 mmol) in $25 \mathrm{~mL} \mathrm{CHCl}_{3}$ was treated with excess of respective salicylate (sodium salicylate/sodium 5-sulfosalicylate) ( $0.56 \mathrm{mmol})$ in $25 \mathrm{~mL} \mathrm{CH}_{3} \mathrm{OH}$ and stirred under reflux for 12 hours [28]. After concentration, the mixture was dissolved in minimum quantity of $\mathrm{CH}_{2} \mathrm{Cl}_{2}$ and extracted four times with distilled water to remove excess salicylic acid/5-sulfosalicylic acid. The lower layer containing compound in $\mathrm{CH}_{2} \mathrm{Cl}_{2}$ was collected, and then it was filtered through anhydrous $\mathrm{Na}_{2} \mathrm{SO}_{4}$ in order to remove water. The compound was recrystallized from dichloromethane-hexane solution $(1: 1)$. The same procedure was applied for the synthesis of all axially ligated zirconium porphyrin complexes as described above. The purified axially ligated zirconium porphyrin complexes were obtained in yields of $40-45 \%$.

(1) SAZrTPP. Red solid. Anal. Calcd. for $\mathrm{C}_{51} \mathrm{H}_{32} \mathrm{~N}_{4} \mathrm{O}_{3} \mathrm{Zr}(\%)$ : C 72.92, H 3.84, N 6.67. Found: C 72.92, H 3.76, N 6.63. UV-vis $\left(\mathrm{CHCl}_{3}\right) \lambda_{\text {max }}: 418 \mathrm{~nm}$ (Soret band), $549 \mathrm{~nm}, 590 \mathrm{~nm}$ (Q-band). ESI-MS ( $\left.\mathrm{CH}_{3} \mathrm{OH}: \mathrm{CH}_{3} \mathrm{CN}\right): \mathrm{m} / z$ calcd. for $\mathrm{C}_{51} \mathrm{H}_{32} \mathrm{~N}_{4} \mathrm{O}_{3} \mathrm{Zr}$ : 840. Found $841\left([\mathrm{M}+\mathrm{H}]^{+}\right)$; IR $(\mathrm{KBr}) \nu_{\max }$ : $485 \mathrm{~cm}^{-1}\left(\nu_{\mathrm{Zr}-\mathrm{N}}\right), 662 \mathrm{~cm}^{-1}\left(\nu_{\mathrm{Zr}-\mathrm{O}}\right.$, phenolic SA $), 719 \mathrm{~cm}^{-1}$ $\left(\nu_{\mathrm{Zr}-\mathrm{O}}\right.$, carboxylic SA $) .{ }^{1} \mathrm{H} \mathrm{NMR}\left(500 \mathrm{MHz}, \mathrm{CDCl}_{3}\right): \delta(\mathrm{ppm})$ $8.93(8 \mathrm{H}, \mathrm{s}$, pyrrole), $8.50(4 \mathrm{H}, \mathrm{s}$, o-phenyl), $8.07(4 \mathrm{H}, \mathrm{d}$, o-phenyl), 7.68 (12H, m, m-phenyl, p-phenyl), $6.98(1 \mathrm{H}$, q, 4-phenyl SA), 6.18 (4H, q, 5-phenyl SA), $6.16(4 \mathrm{H}, \mathrm{d}$, 3-phenyl SA), 6.06 (1H, d, 6-phenyl SA).

(2) 5-SSAZrTPP. Dark reddish brown solid. Anal. Calcd. for $\mathrm{C}_{51} \mathrm{H}_{32} \mathrm{~N}_{4} \mathrm{O}_{6} \mathrm{SZr}(\%)$ : C 66.57, $\mathrm{H}$ 3.51, N 6.09, S 3.48. Found: C 66.53, H 3.64, N 6.07, S 3.48; UV-vis $\left(\mathrm{CHCl}_{3}\right) \lambda_{\text {max }}$ : $420 \mathrm{~nm}$ (Soret band), $549 \mathrm{~nm}, 587 \mathrm{~nm}$ (Q-band). ESI-MS $\left(\mathrm{CH}_{3} \mathrm{OH}: \mathrm{CH}_{3} \mathrm{CN}\right): \mathrm{m} / z$ calcd. for $\mathrm{C}_{51} \mathrm{H}_{32} \mathrm{~N}_{4} \mathrm{O}_{6} \mathrm{SZr}$ : 920; found $921\left([\mathrm{M}+\mathrm{H}]^{+}\right)$. IR $(\mathrm{KBr}) \nu_{\max }: 500 \mathrm{~cm}^{-1}\left(\nu_{\mathrm{Zr}-\mathrm{N}}\right)$, $678 \mathrm{~cm}^{-1}\left(\nu_{\mathrm{Zr}-\mathrm{O}}\right.$, phenolic 5 -SSA $), 722 \mathrm{~cm}^{-1}\left(\nu_{\mathrm{Zr}-\mathrm{O}}\right.$, carboxylic 5-SSA). ${ }^{1} \mathrm{H}$ NMR $\left(500 \mathrm{MHz}, \mathrm{CDCl}_{3}\right): \delta(\mathrm{ppm}) 8.96(8 \mathrm{H}$, s, pyrrole), 8.53 ( $4 \mathrm{H}, \mathrm{s}$, o-phenyl), 8.11 (4H, d, o-phenyl), 7.71 (12H, m, m-phenyl, p-phenyl), 7.10 (1H, q, 4-phenyl 5-SSA), 7.15 (1H, d, 3-phenyl 5-SSA), 7.19 (1H, s, 6-phenyl 5-SSA).

(3) $\mathrm{SAZr}\left(p-\mathrm{CH}_{3} \mathrm{TPP}\right)$. Brown solid. Anal. Calcd. for $\mathrm{C}_{55} \mathrm{H}_{40} \mathrm{~N}_{4} \mathrm{O}_{3} \mathrm{Zr}(\%)$ : C 73.71, H 4.50, N 6.25. Found: C 73.63, $\mathrm{H}$ 4.49, N 6.25; UV-vis $\left(\mathrm{CHCl}_{3}\right) \lambda_{\max }: 422 \mathrm{~nm}$ (Soret band), $547 \mathrm{~nm}, 591 \mathrm{~nm}$ (Q-band). ESI-MS ( $\left.\mathrm{CH}_{3} \mathrm{OH}: \mathrm{CH}_{3} \mathrm{CN}\right): \mathrm{m} / z$ calcd. for $\mathrm{C}_{55} \mathrm{H}_{40} \mathrm{~N}_{4} \mathrm{O}_{3} \mathrm{Zr}$ : 896. Found $897\left([\mathrm{M}+\mathrm{H}]^{+}\right)$. IR $(\mathrm{KBr}) \nu_{\max }: 510 \mathrm{~cm}^{-1}\left(\nu_{\mathrm{Zr}-\mathrm{N}}\right), 683 \mathrm{~cm}^{-1}\left(\nu_{\mathrm{Zr}-\mathrm{O}}\right.$, phenolic SA), $713 \mathrm{~cm}^{-1}\left(\nu_{\mathrm{Zr}-\mathrm{O}}\right.$, carboxylic SA). ${ }^{1} \mathrm{H}$ NMR $(500 \mathrm{MHz}$, $\mathrm{CDCl}_{3}$ ): $\delta$ (ppm) 8.94 (8H, s, pyrrole), 8.42 (4H, s, o-phenyl), $8.15(4 \mathrm{H}, \mathrm{d}$, o-phenyl), $7.71(8 \mathrm{H}, \mathrm{m}, \mathrm{m}$-phenyl), $2.83(12 \mathrm{H}$, s, p- $\left.\mathrm{CH}_{3}\right), 6.93(1 \mathrm{H}, \mathrm{q}, 4$-phenyl SA), 6.22 (4H, q, 5-phenyl SA), 6.15 (4H, d, 3-phenyl SA), 6.04 (1H, d, 6-phenyl SA).

(4) 5-SSAZr $\left(p-\mathrm{CH}_{3} \mathrm{TPP}\right)$. Brown red solid. Anal. Calcd. for $\mathrm{C}_{55} \mathrm{H}_{40} \mathrm{~N}_{4} \mathrm{O}_{6} \mathrm{SZr}(\%)$ : C 67.67, H 4.13, N 5.39, S 3.28. Found: $\mathrm{C} 68.14, \mathrm{H}$ 4.21, $\mathrm{N}$ 5.56, S 3.88. UV-vis $\left(\mathrm{CHCl}_{3}\right) \lambda_{\text {max }}$ : $423 \mathrm{~nm}$ (Soret band), $551 \mathrm{~nm}, 593 \mathrm{~nm}$ (Q-band). ESI-MS $\left(\mathrm{CH}_{3} \mathrm{OH}: \mathrm{CH}_{3} \mathrm{CN}\right): \mathrm{m} / z$ calcd for $\mathrm{C}_{55} \mathrm{H}_{40} \mathrm{~N}_{4} \mathrm{O}_{6} \mathrm{SZr}$ : 974. Found $975\left([\mathrm{M}+\mathrm{H}]^{+}\right)$. IR $(\mathrm{KBr}) v_{\max }: 517 \mathrm{~cm}^{-1}\left(\nu_{\mathrm{Zr}-\mathrm{N}}\right)$, $685 \mathrm{~cm}^{-1}\left(\nu_{\mathrm{Zr}-\mathrm{O}}\right.$, phenolic SA $), 715 \mathrm{~cm}^{-1}\left(\nu_{\mathrm{Zr}-\mathrm{O}}\right.$, carboxylic 5-SSA). ${ }^{1} \mathrm{H}$ NMR $\left(500 \mathrm{MHz}, \mathrm{CDCl}_{3}\right): \delta(\mathrm{ppm}) 8.96(8 \mathrm{H}, \mathrm{s}$, pyrrole), 8.47 (4H, s, o-phenyl), 8.18 (4H, s, o-phenyl), $7.78\left(8 \mathrm{H}, \mathrm{m}, \mathrm{m}\right.$-phenyl), $2.85\left(12 \mathrm{H}, \mathrm{s}, \mathrm{p}-\mathrm{CH}_{3}\right), 7.06(1 \mathrm{H}, \mathrm{q}$, 4-phenyl 5-SSA), 7.08 (1H, d, 3-phenyl 5-SSA), 7.17 (1H, s, 6-phenyl 5-SSA).

(5) $\operatorname{SAZr}(p-C l T P P)$. Red solid. Anal. Calcd. for $\mathrm{C}_{51} \mathrm{H}_{28} \mathrm{Cl}_{4} \mathrm{~N}_{4} \mathrm{O}_{3} \mathrm{Zr}(\%)$ : $\mathrm{C}$ 62.64, $\mathrm{H}$ 2.89, $\mathrm{N}$ 5.73. Found: $\mathrm{C} 60.12, \mathrm{H} 2.84, \mathrm{~N} 10.97$; UV-vis spectra $\left(\mathrm{CHCl}_{3}\right) \lambda_{\text {max }}$ : $421 \mathrm{~nm}$ (Soret band), $551 \mathrm{~nm}, 594 \mathrm{~nm}$ (Q-band). ESI-MS $\left(\mathrm{CH}_{3} \mathrm{OH}: \mathrm{CH}_{3} \mathrm{CN}\right): \mathrm{m} / z$ calcd for $\mathrm{C}_{51} \mathrm{H}_{28} \mathrm{Cl}_{4} \mathrm{~N}_{4} \mathrm{O}_{3} \mathrm{Zr}$ : 978; found $979\left([\mathrm{M}+\mathrm{H}]^{+}\right)$. IR $(\mathrm{KBr}) \nu_{\max }: 488 \mathrm{~cm}^{-1}\left(\nu_{\mathrm{Zr}-\mathrm{N}}\right)$, $658 \mathrm{~cm}^{-1}\left(\nu_{\mathrm{Zr}-\mathrm{O}}\right.$, phenolic SA $), 721 \mathrm{~cm}^{-1}\left(\nu_{\mathrm{Zr}-\mathrm{O}}\right.$, carboxylic $\mathrm{SA}) .{ }^{1} \mathrm{H}$ NMR $\left(500 \mathrm{MHz}, \mathrm{CDCl}_{3}\right): \delta(\mathrm{ppm}) 9.12(8 \mathrm{H}, \mathrm{s}$, pyrrole), 8.42 (4H, d, o-phenyl), 8.17 (4H, m, o-phenyl), $8.02(8 \mathrm{H}, \mathrm{m}, \mathrm{m}$-phenyl), $6.98(1 \mathrm{H}, \mathrm{q}, 4$-phenyl SA), 6.30 $(1 \mathrm{H}, \mathrm{q}, 5$-phenyl SA), $6.26(4 \mathrm{H}, \mathrm{d}, 3$-phenyl SA), $6.16(1 \mathrm{H}, \mathrm{d}$, 6-phenyl SA).

(6) 5-SSAZr(p-ClTPP). Brown solid. Anal. Calcd. for $\mathrm{C}_{51} \mathrm{H}_{28} \mathrm{Cl}_{4} \mathrm{~N}_{4} \mathrm{O}_{6} \mathrm{SZr}(\%)$ : C 57.90, H 2.67, N 5.30, S 3.03. Found: C 55.64, H 2.53, N 10.23, S 3.32. UV-vis $\left(\mathrm{CHCl}_{3}\right) \lambda_{\text {max }}$ : $421 \mathrm{~nm}$ (Soret band), $552 \mathrm{~nm}, 595 \mathrm{~nm}$ (Q-band). ESI-MS 
$\left(\mathrm{CH}_{3} \mathrm{OH}: \mathrm{CH}_{3} \mathrm{CN}\right): \mathrm{m} / z$ calcd. for $\mathrm{C}_{51} \mathrm{H}_{28} \mathrm{Cl}_{4} \mathrm{~N}_{4} \mathrm{O}_{6} \mathrm{SZr}: 1057$. Found $1058\left([\mathrm{M}+\mathrm{H}]^{+}\right)$. IR $(\mathrm{KBr}) v_{\max }: 492 \mathrm{~cm}^{-1}\left(v_{\mathrm{Zr}-\mathrm{N}}\right)$, $660 \mathrm{~cm}^{-1}\left(v_{\mathrm{Zr}-\mathrm{O}}\right.$, phenolic SA), $722 \mathrm{~cm}^{-1}\left(v_{\mathrm{Zr}-\mathrm{O}}\right.$, carboxylic $\mathrm{SA}) .{ }^{1} \mathrm{H}$ NMR $\left(500 \mathrm{MHz}, \mathrm{CDCl}_{3}\right): \delta(\mathrm{ppm}) 9.25(8 \mathrm{H}, \mathrm{s}$, pyrrole), $8.46(4 \mathrm{H}, \mathrm{s}$, o-phenyl), 8.23 (4H, s, o-phenyl), 8.09 $(8 \mathrm{H}, \mathrm{s}, \mathrm{m}$-phenyl), $7.09(1 \mathrm{H}, \mathrm{q}, 4$-phenyl 5-SSA), $7.15(1 \mathrm{H}, \mathrm{d}$, 3-phenyl 5-SSA), 7.20 (1H, s, 6-phenyl 5-SSA).

(7) $\operatorname{SAZr}\left(p-\mathrm{NO}_{2} \mathrm{TPP}\right)$. Red solid. Anal. Calcd. for $\mathrm{C}_{51} \mathrm{H}_{28} \mathrm{~N}_{8} \mathrm{O}_{11} \mathrm{Zr}(\%): \mathrm{C} 60.05, \mathrm{H} 2.77, \mathrm{~N}$ 10.99. Found: C 68.73, $\mathrm{H}$ 4.22, N 5.79. UV-vis $\left(\mathrm{CHCl}_{3}\right) \lambda_{\text {max }}: 424 \mathrm{~nm}$ (Soret band), $548 \mathrm{~nm}, 594 \mathrm{~nm}$ (Q-band). ESI-MS $\left(\mathrm{CH}_{3} \mathrm{OH}: \mathrm{CH}_{3} \mathrm{CN}\right): \mathrm{m} / z$ calcd. for $\mathrm{C}_{51} \mathrm{H}_{28} \mathrm{~N}_{8} \mathrm{O}_{11} \mathrm{Zr}$ : 1020; found $1021\left([\mathrm{M}+\mathrm{H}]^{+}\right)$. IR $(\mathrm{KBr}) \nu_{\max }: 483 \mathrm{~cm}^{-1}\left(\nu_{\mathrm{Zr}-\mathrm{N}}\right), 654 \mathrm{~cm}^{-1}\left(\nu_{\mathrm{Zr}-\mathrm{O}}\right.$, phenolic SA), $724 \mathrm{~cm}^{-1}$ ( $\nu_{\mathrm{Zr}-\mathrm{O}}$, carboxylic SA). ${ }^{1} \mathrm{H}$ NMR $(500 \mathrm{MHz}$, $\left.\mathrm{CDCl}_{3}\right): \delta(\mathrm{ppm}) 9.17(8 \mathrm{H}, \mathrm{s}$, pyrrole), $8.42(4 \mathrm{H}, \mathrm{d}, \mathrm{o}$-phenyl), $8.07(4 \mathrm{H}, \mathrm{d}, \mathrm{o}$-phenyl), $7.64(8 \mathrm{H}, \mathrm{s}, \mathrm{m}$-phenyl), $7.05(1 \mathrm{H}, \mathrm{q}$, 4-phenyl SA), 6.55 (1H, q, 5-phenyl SA), 6.50 (1H, d, 3-phenyl SA), 6.18 (1H, d, 6-phenyl SA).

(8) 5-SSAZr $\left(p-\mathrm{NO}_{2} \mathrm{TPP}\right)$. Red solid. Anal. Calcd. for $\mathrm{C}_{51} \mathrm{H}_{28} \mathrm{~N}_{8} \mathrm{SO}_{14} \mathrm{Zr}(\%)$ : C 55.68, H 2.57, N 10.19, S 2.91. Found: C 63.89, H 3.86, N 5.45, S 3.21. UV-vis $\left(\mathrm{CHCl}_{3}\right) \lambda_{\max }$ : $425 \mathrm{~nm}$ (Soret band), $550 \mathrm{~nm}, 594 \mathrm{~nm}$ (Q-band). ESI-MS $\left(\mathrm{CH}_{3} \mathrm{OH}: \mathrm{CH}_{3} \mathrm{CN}\right): \mathrm{m} / z$ calcd. for $\mathrm{C}_{51} \mathrm{H}_{28} \mathrm{~N}_{8} \mathrm{SO}_{14} \mathrm{Zr}$ : 1100; found $1101\left([\mathrm{M}+\mathrm{H}]^{+}\right)$. IR $(\mathrm{KBr}) v_{\max }: 487 \mathrm{~cm}^{-1}\left(\nu_{\mathrm{Zr}-\mathrm{N}}\right)$, $667 \mathrm{~cm}^{-1}\left(\nu_{\mathrm{Zr}-\mathrm{O}}\right.$, phenolic SA), $728 \mathrm{~cm}^{-1}\left(\nu_{\mathrm{Zr}-\mathrm{O}}\right.$, carboxylic $\mathrm{SA}) .{ }^{1} \mathrm{H}$ NMR $\left(500 \mathrm{MHz}, \mathrm{CDCl}_{3}\right): \delta(\mathrm{ppm}) 9.26(8 \mathrm{H}, \mathrm{s}$, pyrrole), $8.45(4 \mathrm{H}, \mathrm{s}$, o-phenyl), $8.11(4 \mathrm{H}, \mathrm{d}$, o-phenyl), 7.65 $(8 \mathrm{H}, \mathrm{m}, \mathrm{m}$-phenyl), $7.23(1 \mathrm{H}, \mathrm{q}, 4$-phenyl 5-SSA), $7.78(1 \mathrm{H}, \mathrm{d}$, 3-phenyl 5-SSA), 7.92 (1H, s, 6-phenyl 5-SSA).

\section{Results and Discussion}

3.1. Synthesis and Characterization. The general synthetic routes to peripherally tetrasubstituted tetraphenylporphyrin derivatives (RTPP), their corresponding metallated, and axially ligated zirconium(IV) porphyrins are shown in Schemes 1,2 , and 3 , respectively. All of these new zirconium(IV) porphyrins were purified by column chromatography with aluminum oxide as adsorbent and were characterized by spectral data (UV-visible spectroscopy, IR spectroscopy, ${ }^{1} \mathrm{H}$ NMR spectroscopy, mass spectral data, and elemental analysis). The characterization data of the new compounds are consistent with the assigned formula. All the free base porphyrins, substituted tetraphenylporphyrin zirconium(IV) chlorides, and substituted tetraphenylporphyrin zirconium(IV) salicylates, are water insoluble.

3.1.1. Spectral Analysis of $\mathrm{Cl}_{2} Z r(I V) R T P P$ and SA/5SSAZr(IV)RTPP. The structures of all free base porphyrins (RTPP), substituted tetraphenylporphyrin zirconium(IV) chlorides $\mathrm{Cl}_{2} \mathrm{Zr}(\mathrm{IV}) \mathrm{RTPP}$ and substituted tetraphenylporphyrin zirconium(IV) salicylates (SA/5-SSAZr(IV)RTPP), are characterized by UV-vis, and the spectral data are listed in Tables 1 and 2. The UV-vis data shows that many of the absorption bands of the parasubstituted derivatives exhibit small shifts to longer wavelength, that is, bathochromic shift (red shift) as compared to the spectrum of TPP. The most
TABLE 1: UV-vis data of free base porphyrins and corresponding tetraphenylporphyrin zirconium(IV) chlorides complexes in chloroform.

\begin{tabular}{lccc}
\hline No. & \multirow{2}{*}{ Compound } & \multicolumn{2}{c}{$\lambda_{\max }(\mathrm{nm})$} \\
\hline 1 & $\mathrm{TPP}$ & 418 & Q-band \\
2 & $\mathrm{p}-\mathrm{CH}_{3} \mathrm{TPP}$ & 419 & $515,552,590,646$ \\
3 & $\mathrm{p}-\mathrm{ClTPP}$ & 422 & $519,552,592,646$ \\
4 & $\mathrm{p}-\mathrm{NO}_{2} \mathrm{TPP}$ & 423 & $516,552,592,655$ \\
5 & $\mathrm{Cl}_{2} \mathrm{ZrTPP}$ & 407 & 541 \\
6 & $\mathrm{Cl}_{2} \mathrm{Zr}\left(\mathrm{p}-\mathrm{CH}_{3} \mathrm{TPP}\right)$ & 409 & 540 \\
7 & $\mathrm{Cl}_{2} \mathrm{Zr}(\mathrm{p}-\mathrm{ClPP})$ & 416 & 540 \\
8 & $\mathrm{Cl}_{2} \mathrm{Zr}\left(\mathrm{p}-\mathrm{NO}_{2} \mathrm{TPP}\right)$ & 416 & 542 \\
\hline
\end{tabular}

pronounced bathochromic shift occurs in $\mathrm{p}-\mathrm{NO}_{2} \mathrm{TPP}$ with paranitro group on mesophenyl ring of the porphyrin but in all the substituted tetraphenylporphyrin, intensities of all the peaks are higher than those of the parent tetraphenylporphyrin. The reason might be that the strong electronwithdrawing- $\mathrm{NO}_{2}$ group decreased the electronic density of the porphyrin ring. Thus, the $\pi-\pi^{*}$ electron excitation of the porphyrin ring required absorbing the light of smaller energy (longer wavelength).

By comparing the UV-vis data in Table 1, it was noticed that in the visible absorption spectra, free base porphyrins show an intense absorption, referred to as the Soret band at around $400 \mathrm{~nm}$ and four weaker absorptions known as Q bands between $450 \mathrm{~nm}$ and $800 \mathrm{~nm}$. When the metal ion was inserted into the porphyrin ring, the number and intensity of the Q bands were found to decrease and the B (Soret) band showed a slight blue shift (Figure 1). The reason might be that the structural symmetry of zirconium(IV) porphyrin compounds was improved and the energy gap decreased as compared to the free base porphyrins [29]. In axially ligated zirconium(IV) porphyrin complexes, both B- and Q-bands regions of the spectra show slight red shift. The red shift may be due to structural distortion in the porphyrin macrocycle and concomitant electronic coupling of the metalloporphyrin to the salicylate mediated by the zirconium metal ion [18]. The optical absorption spectra of the compounds of the axially ligated zirconium(IV) porphyrins were when recorded in different solvents; only marginal changes of $\lambda_{\max }$ values, absorption coefficient $(\varepsilon)$, and oscillatory strength $(f)$ were observed. It is found that with the increase in polarity of the solvents, B- and Q-bands in axially ligated $\mathrm{Zr}$ (IV) metal derivatives with different porphyrins show a slight red shift with progressive broadening of bands indicating that the magnitude of red shift of B- and Q-bands depends on the nature of the solvent used. This is so since excited state is more polar than the ground state and hence stabilization is greater relative to the ground state in polar solvents. It is observed that for all the axially ligated $\mathrm{Zr}(\mathrm{IV})$ derivatives, Band Q-bands exhibit a red shift on increasing the polarity of the solvents in the order: acetone > chloroform > toluene (Figure 2). The magnitude of change of the " $f$ " values in 


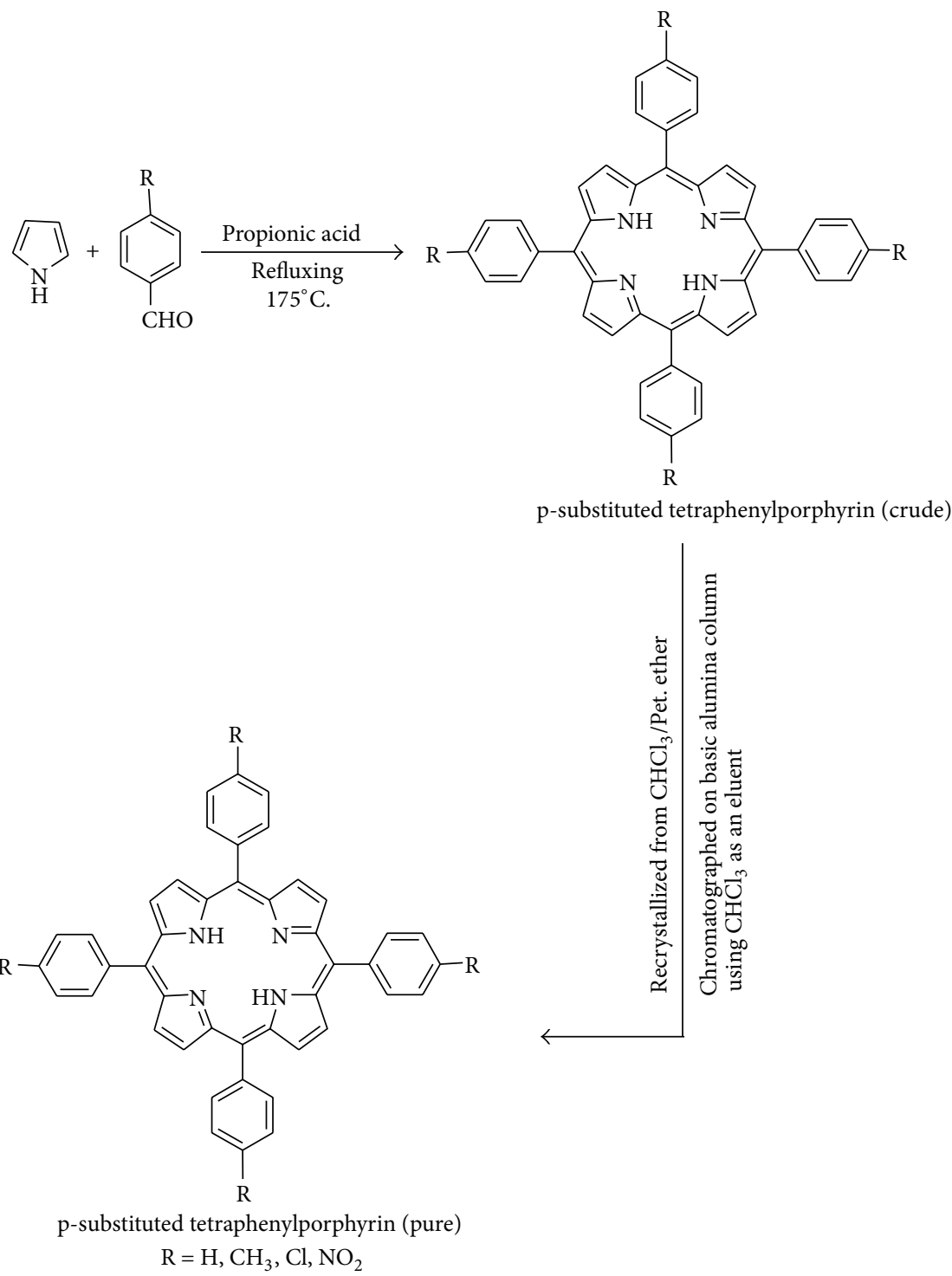

SCHEME 1: General synthetic route for the synthesis of tetraphenylporphyrin and its parasubstituted derivatives.

axially ligated $\mathrm{Zr}(\mathrm{IV})$ metal derivatives of porphyrins reveal the relative strength of interaction.

Infrared spectral data of above porphyrin compounds is listed in Table 3. It is found that the $v(\mathrm{~N}-\mathrm{H})$ stretching and bending frequencies of free base porphyrins are located at $\sim 3400-3320 \mathrm{~cm}^{-1}$ and $\sim 960 \mathrm{~cm}^{-1}$, respectively [30]. When the zirconium ion was inserted into the porphyrin ring, the $\mathrm{N}-\mathrm{H}$ vibration frequency of free base porphyrins disappeared and the characteristic $v(\mathrm{Zr}-\mathrm{N})$ vibration frequency was found at $\sim 500-400 \mathrm{~cm}^{-1}$, which indicated the formation of zirconium(IV) porphyrin compounds [31]. In the spectra of all the axially ligated zirconium(IV) porphyrin complexes, the band due to $v(\mathrm{O}-\mathrm{H})$ of the ligand disappeared indicating the coordination of phenolic oxygen to the metal via deprotonation [32]. The band assigned to the $v(\mathrm{C}-\mathrm{O})$ stretching show upward shift in the range $\sim 1264-1249 \mathrm{~cm}^{-1}$, which is due to the coordination of the phenolic oxygen to $\mathrm{Zr}$ (IV) porphyrins [33]. The incorporation of salicylates in $\mathrm{Zr}(\mathrm{IV})$ metal derivatives of different porphyrins, that is, SA/5-SSAZrRTPP, is further confirmed by the appearance of $\mathrm{Zr}-\mathrm{O}$ vibrational frequencies in the range $690-662 \mathrm{~cm}^{-1}$ and $740-719 \mathrm{~cm}^{-1}$ corresponding to the ligation of zirconium to oxygen of phenolic and carboxylic groups of salicylate, respectively. Thus, the zirconium atom in the centre of porphyrin ring coordinates with the salicylate group axially to form six-coordinate complex of $\mathrm{Zr}$ (IV) porphyrin.

${ }^{1} \mathrm{H}$ NMR data of free base porphyrin, their corresponding metallated, and axially ligated zirconium(IV) porphyrin complexes in $\mathrm{CDCl}_{3}$ at $298 \mathrm{~K}$ is listed Table 4 . In all the metallated porphyrins, there was absence of signal related to $\mathrm{N}-$ $\mathrm{H}$ protons and shift in other signals indicating the insertion of zirconium in porphyrin macrocycle [31]. Generally, the presence of $\mathrm{Zr}(\mathrm{IV})$ metal in the porphyrin ring shifts the resonances of the porphyrin's protons to downfield accompanied 
<smiles></smiles>

(i) Refluxingin benzonitrite at 195-200 ${ }^{\circ} \mathrm{C}$ for $1-3$ hours

(ii) Distilling benzonitrile off in a vaccum (iii) Chromatographed on basic $\mathrm{Al}_{2} \mathrm{O}_{3}$ using $\mathrm{CHCl}_{3}$ as eluent

(iv) Recrystallized from $\mathrm{CHCl}_{3} /$ Pet. ether

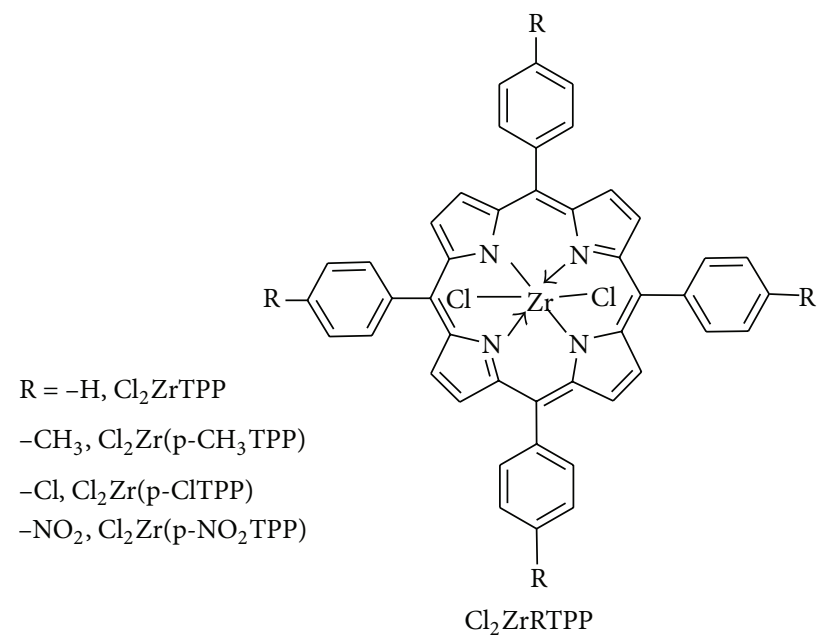

Scheme 2: General synthetic route for the synthesis of dichloro(tetraarylporphinato)zirconium(IV).

by marginal changes in the pattern. One of the important features of axially ligated $\mathrm{Zr}(\mathrm{IV})$ derivatives of porphyrins is that the metal is almost out of the plane of the porphyrin ring which has earlier been reviewed in the literature, responsible for the production of asymmetric environment above and below the plane of the macrocycle which ultimately accounts for the pronounced nonequivalence of the orthoprotons of the phenyl rings. In axially ligated zirconium(IV) porphyrin complexes, the signals of axial salicylic and 5-sulfosalicylic fragment protons are shifted to higher field in comparison to the signals of porphyrin protons and also in comparison to proton signals of free salicylic and 5-sulfosalicylic acids respectively [34]. These positions of protons show that axial ligand is under the influence of $\pi$-conjugated system of porphyrin macrocycle [22]. This is most probably due to deshielding effect resulting from the $\sigma$-donation of electron density upon bond formation as compared to the shielding effect of the porphyrin.

Mass spectrometric characterization of SA/5-SSAZrRTPP complexes employed ESI as soft ionization technique. The mass spectra of axial ligated zirconium(IV) porphyrins with salicylic acid/5-sulfosalicylic acid are characterized by the presence of the molecular ion peak for monomeric form followed by a degree of fragmentation when employing this technique, which suggested that axial ligand was labile. The substituents such as sulphonates in the axial ligand were labile too. The major losses are 81,104 , and 33 corresponding to the loss of $\mathrm{SO}_{3} \mathrm{H}$ group, salicylic fragment, and $\mathrm{H}_{2} \mathrm{O}$ molecules. The obtained ESI-MS data display that the molecule of axially ligated zirconium(IV) porphyrins contain one or two molecules of solvent coordinated to the central zirconium atom, which are not labile sufficiently and present in all 
TABLE 2: UV-vis data of salicylate/5-sulfosalicylate ligated zirconium(IV) complexes in different solvents.

\begin{tabular}{|c|c|c|c|c|c|c|c|}
\hline \multirow{2}{*}{ Complex } & \multirow{2}{*}{ Solvent } & \multicolumn{3}{|c|}{$\lambda_{\max }, \mathrm{nm}\left(\log \varepsilon, \mathrm{M}^{-1} \mathrm{~cm}^{-1}\right)$} & \multicolumn{2}{|c|}{$v_{1 / 2}\left(\mathrm{~cm}^{-1}\right)$} & \multirow{2}{*}{$\begin{array}{c}f \\
\mathrm{~B}(0,0) \\
\end{array}$} \\
\hline & & $\mathrm{B}(0,0)$ & $\mathrm{Q}(1,0)$ & $\mathrm{Q}(0,0)$ & $\mathrm{B}(0,0)$ & $\mathrm{Q}(1,0)$ & \\
\hline \multirow{3}{*}{ SAZrTPP } & Acetone & $420(4.8691)$ & $549(3.544)$ & $586(2.278)$ & 1123 & 792.3 & 0.351 \\
\hline & Chloroform & $418(4.7862)$ & $549(3.362)$ & $590(2.398)$ & 1134 & 796.6 & 0.307 \\
\hline & Toluene & $417(4.7686)$ & $547(3.255)$ & $585(2.176)$ & 1151 & 808.4 & 0.292 \\
\hline \multirow{3}{*}{ 5-SSAZrTPP } & Acetone & $422(4.8651)$ & $550(3.579)$ & $590(2.954)$ & 1120 & 796.6 & 0.352 \\
\hline & Chloroform & $420(4.8463)$ & $549(3.414)$ & $587(2.903)$ & 1123 & 794.9 & 0.340 \\
\hline & Toluene & $417(4.8331)$ & $545(3.301)$ & $585(2.778)$ & 1135 & 802.5 & 0.335 \\
\hline \multirow{3}{*}{$\mathrm{SAZr}\left(\mathrm{p}-\mathrm{CH}_{3} \mathrm{TPP}\right)$} & Acetone & $424(4.8847)$ & $548(3.362)$ & $593(2.994)$ & 1110 & 799.6 & 0.368 \\
\hline & Chloroform & $422(4.8691)$ & $547(3.278)$ & $591(2.972)$ & 1123 & 800.8 & 0.350 \\
\hline & Toluene & $419(4.8475)$ & $547(3.230)$ & $589(2.968)$ & 1138 & 802.2 & 0.347 \\
\hline \multirow{3}{*}{ 5-SSAZr $\left(\mathrm{p}-\mathrm{CH}_{3} \mathrm{TPP}\right)$} & Acetone & $425(4.8948)$ & $553(3.672)$ & $594(3.064)$ & 1106 & 785.2 & 0.370 \\
\hline & Chloroform & $423(4.8615)$ & $551(3.362)$ & $593(3.334)$ & 1118 & 789.3 & 0.353 \\
\hline & Toluene & $418(4.8518)$ & $547(3.447)$ & $590(3.230)$ & 1143 & 802.5 & 0.351 \\
\hline \multirow{3}{*}{ SAZr(p-ClTPP) } & Acetone & $423(4.8651)$ & $553(3.518)$ & $596(2.976)$ & 1151 & 785.1 & 0.365 \\
\hline & Chloroform & $421(4.8312)$ & $551(3.322)$ & $594(2.970)$ & 1127 & 788.3 & 0.331 \\
\hline & Toluene & $419(4.7951)$ & $551(3.114)$ & $590(2.930)$ & 1134 & 790.7 & 0.304 \\
\hline \multirow{3}{*}{ 5-SSAZr(p-ClTPP) } & Acetone & $424(4.8759)$ & $552(3.518)$ & $597(3.079)$ & 1103 & 787.7 & 0.357 \\
\hline & Chloroform & $421(4.8318)$ & $552(3.342)$ & $595(2.973)$ & 1126 & 793.8 & 0.331 \\
\hline & Toluene & $421(4.7951)$ & $549(3.176)$ & $590(2.942)$ & 1129 & 796.7 & 0.305 \\
\hline \multirow{3}{*}{$\mathrm{SAZr}\left(\mathrm{p}-\mathrm{NO}_{2} \mathrm{TPP}\right)$} & Acetone & $424(4.9647)$ & $551(3.5051)$ & $596(3.041)$ & 1110 & 790.0 & 0.328 \\
\hline & Chloroform & $424(4.7331)$ & $548(3.397)$ & $594(2.984)$ & 1125 & 798.7 & 0.292 \\
\hline & Toluene & $422(4.6599)$ & $547(3.230)$ & $593(2.943)$ & 1129 & 799.6 & 0.291 \\
\hline \multirow{3}{*}{ 5-SSAZr $\left(\mathrm{p}-\mathrm{NO}_{2} \mathrm{TPP}\right)$} & Acetone & $423(4.9498)$ & $547(3.447)$ & $598(3.149)$ & 1106 & 787.6 & 0.330 \\
\hline & Chloroform & $425(4.7259)$ & $550(3.362)$ & $594(3.124)$ & 1120 & 793.3 & 0.306 \\
\hline & Toluene & $422(4.6541)$ & $547(3.204)$ & $594(3.082)$ & 1128 & 802.1 & 0.267 \\
\hline
\end{tabular}

TABLE 3: Main infrared absorption frequencies of free base porphyrins, their corresponding metallated, and axially ligated Zr(IV) porphyrin complexes.

\begin{tabular}{|c|c|c|c|c|c|c|c|c|c|c|c|}
\hline \multirow{2}{*}{ Compound } & \multicolumn{11}{|c|}{$\operatorname{IR}\left(\mathrm{cm}^{-1}\right)$} \\
\hline & $\nu_{\mathrm{N}-\mathrm{H}}$ & $v_{\mathrm{C}-\mathrm{H}}$ & $v_{\mathrm{Zr}-\mathrm{O}}$ & $\gamma_{\mathrm{C}-\mathrm{H}}$ & $\nu_{\mathrm{C}=\mathrm{N}}$ & $v_{\mathrm{C}=\mathrm{O}}$ & $v_{\mathrm{Zr}-\mathrm{N}}$ & $v_{\mathrm{SO}_{2}}$ & $\nu_{\mathrm{PhCO}}$ & $v_{\mathrm{Zr}-\mathrm{O}}$ & $v_{\mathrm{OCO}}$ \\
\hline TPP & 3326 & 2963 & - & 797 & 1349 & - & - & - & - & - & - \\
\hline $\mathrm{Cl}_{2} \mathrm{ZrTPP}$ & - & 2960 & - & 800 & 1351 & - & 485 & - & - & - & - \\
\hline SAZrTPP & - & 2961 & 662 & 800 & 1328 & 1731 & 485 & - & 1260 & 719 & 1379 \\
\hline 5-SSAZrTPP & - & 2960 & 678 & 801 & 1336 & 1730 & 500 & 1156,1074 & 1264 & 722 & 1378 \\
\hline $\mathrm{p}-\mathrm{CH}_{3} \mathrm{TPP}$ & 3416 & 2964 & - & 794 & 1350 & - & - & - & - & - & - \\
\hline $\mathrm{Cl}_{2} \mathrm{Zr}\left(\mathrm{p}-\mathrm{CH}_{3} \mathrm{TPP}\right)$ & - & 2955 & - & 800 & 1339 & - & 508 & - & - & - & - \\
\hline $\mathrm{SAZr}\left(\mathrm{p}-\mathrm{CH}_{3} \mathrm{TPP}\right)$ & - & 2956 & 683 & 800 & 1335 & 1735 & 510 & - & 1260 & 713 & 1377 \\
\hline 5-SSAZr $\left(\mathrm{p}-\mathrm{CH}_{3} \mathrm{TPP}\right)$ & - & 2954 & 685 & 803 & 1329 & 1729 & 517 & 1172,1119 & 1261 & 715 & 1379 \\
\hline p-ClTPP & 3428 & 2964 & - & 797 & 1354 & - & - & - & - & - & - \\
\hline $\mathrm{Cl}_{2} \mathrm{Zr}(\mathrm{p}-\mathrm{ClTPP})$ & - & 2962 & - & 803 & 1338 & - & 485 & - & - & - & - \\
\hline SAZr(p-ClTPP) & - & 2961 & 658 & 801 & 1328 & 1729 & 488 & - & 1258 & 721 & 1377 \\
\hline 5-SSAZr(p-ClTPP) & - & 2961 & 660 & 802 & 1336 & 1726 & 492 & 1181,1124 & 1260 & 722 & 1378 \\
\hline $\mathrm{p}-\mathrm{NO}_{2} \mathrm{TPP}$ & 3449 & 2964 & - & 800 & 1329 & - & - & - & - & - & - \\
\hline $\mathrm{Cl}_{2} \mathrm{Zr}\left(\mathrm{p}-\mathrm{NO}_{2} \mathrm{TPP}\right)$ & - & 2952 & - & 802 & 1332 & - & 482 & - & - & - & - \\
\hline $\mathrm{SAZr}\left(\mathrm{p}-\mathrm{NO}_{2} \mathrm{TPP}\right)$ & - & 2945 & 654 & 800 & 1335 & 1728 & 483 & - & 1259 & 724 & 1375 \\
\hline 5-SSAZr(p-NO $\left.{ }_{2} \mathrm{TPP}\right)$ & - & 2938 & 667 & 806 & 1337 & 1725 & 487 & 1174,1124 & 1261 & 728 & 1378 \\
\hline
\end{tabular}


TABLE $4:{ }^{1} \mathrm{H}$ NMR data of free base porphyrin and their zirconium(IV) porphyrins complexes in $\mathrm{CDCl}_{3}$ at $298 \mathrm{~K}$.

\begin{tabular}{|c|c|c|c|c|}
\hline \multirow{2}{*}{ Compound } & \multicolumn{3}{|c|}{ Porphyrin's $\delta$, ppm } & \multirow{2}{*}{ Salicylate protons $\delta$, ppm } \\
\hline & $\mathrm{N}-\mathrm{H}$ & $\beta-\mathrm{H}$ & Meso-H & \\
\hline TPP & $-2.76(\mathrm{~s}, 2 \mathrm{H})$ & $8.82(\mathrm{~s}, 8 \mathrm{H})$ & $\begin{array}{c}8.27\left(\mathrm{~s}, 8 \mathrm{H}, \mathrm{H}_{\mathrm{o}}\right) \\
7.60\left(\mathrm{~s}, 12 \mathrm{H}, \mathrm{H}_{\mathrm{m}, \mathrm{p}}\right)\end{array}$ & - \\
\hline $\mathrm{Cl}_{2} \mathrm{ZrTPP}$ & & $8.87(\mathrm{~s}, 8 \mathrm{H})$ & $\begin{array}{c}8.32\left(\mathrm{~d}, 4 \mathrm{H}, \mathrm{H}_{\mathrm{o}}\right) \\
8.04\left(\mathrm{~d}, 4 \mathrm{H}, \mathrm{H}_{\mathrm{o}}\right) \\
7.64\left(\mathrm{~s}, 12 \mathrm{H}, \mathrm{H}_{\mathrm{m}, \mathrm{p}}\right)\end{array}$ & - \\
\hline SAZrTPP & & $8.93(\mathrm{~s}, 8 \mathrm{H})$ & $\begin{array}{c}8.50\left(\mathrm{~s}, 4 \mathrm{H}, \mathrm{H}_{\mathrm{o}}\right) \\
8.07\left(\mathrm{~d}, 4 \mathrm{H}, \mathrm{H}_{\mathrm{o}}\right) \\
7.68\left(\mathrm{~m}, 12 \mathrm{H}, \mathrm{H}_{\mathrm{m}, \mathrm{p}}\right)\end{array}$ & $\begin{array}{l}6.06\left(\mathrm{~d}, \mathrm{H}_{6}\right) \\
6.18\left(\mathrm{q}, \mathrm{H}_{5}\right) \\
6.98\left(\mathrm{q}, \mathrm{H}_{4}\right) \\
6.16\left(\mathrm{~m}_{3} \mathrm{H}_{3}\right)\end{array}$ \\
\hline 5-SSAZrTPP & & $8.96(\mathrm{~s}, 8 \mathrm{H})$ & $\begin{array}{c}8.53\left(\mathrm{~s}, 4 \mathrm{H}, \mathrm{H}_{\mathrm{o}}\right) \\
8.11\left(\mathrm{~s}, 4 \mathrm{H}, \mathrm{H}_{\mathrm{o}}\right) \\
7.71\left(\mathrm{~m}, 12 \mathrm{H}, \mathrm{H}_{\mathrm{m}, \mathrm{p}}\right)\end{array}$ & $\begin{array}{l}7.19\left(\mathrm{~s}, 1 \mathrm{H}, \mathrm{H}_{6}\right) \\
7.15\left(\mathrm{~d}, 1 \mathrm{H}, \mathrm{H}_{3}\right) \\
7.10\left(\mathrm{q}, 1 \mathrm{H}, \mathrm{H}_{4}\right)\end{array}$ \\
\hline $\mathrm{p}-\mathrm{CH}_{3} \mathrm{TPP}$ & $-2.75(\mathrm{~s}, 2 \mathrm{H})$ & $8.78(\mathrm{~s}, 8 \mathrm{H})$ & $\begin{array}{c}8.18\left(\mathrm{~s}, 8 \mathrm{H}, \mathrm{H}_{\mathrm{o}}\right) \\
7.56\left(\mathrm{~s}, 8 \mathrm{H}, \mathrm{H}_{\mathrm{m}}\right) \\
2.64\left(\mathrm{~s}, 12 \mathrm{H}, \mathrm{H}_{\mathrm{CH} 3}\right)\end{array}$ & - \\
\hline $\mathrm{Cl}_{2} \mathrm{Zr}\left(\mathrm{p}-\mathrm{CH}_{3} \mathrm{TPP}\right)$ & & $8.80(\mathrm{~s}, 8 \mathrm{H})$ & $\begin{array}{c}8.28\left(\mathrm{~d}, 4 \mathrm{H}, \mathrm{H}_{\mathrm{o}}\right) \\
8.00\left(\mathrm{~s}, 4 \mathrm{H}, \mathrm{H}_{\mathrm{o}}\right) \\
7.65\left(\mathrm{~s}, 8 \mathrm{H}, \mathrm{H}_{\mathrm{m}}\right) \\
2.70\left(\mathrm{~s}, 12 \mathrm{H}, \mathrm{H}_{\mathrm{CH} 3}\right)\end{array}$ & - \\
\hline $\mathrm{SAZr}\left(\mathrm{p}-\mathrm{CH}_{3} \mathrm{TPP}\right)$ & & $8.94(\mathrm{~s}, 8 \mathrm{H})$ & $\begin{array}{c}8.42\left(\mathrm{~d}, 4 \mathrm{H}, \mathrm{H}_{\mathrm{o}}\right) \\
8.15\left(\mathrm{~m}, 4 \mathrm{H}, \mathrm{H}_{\mathrm{o}}\right) \\
7.71\left(\mathrm{~m}, 8 \mathrm{H}, \mathrm{H}_{\mathrm{m}}\right) \\
2.83\left(\mathrm{~s}, 12 \mathrm{H}, \mathrm{H}_{\mathrm{CH}_{3}}\right)\end{array}$ & $\begin{array}{l}6.04\left(\mathrm{~d}, \mathrm{H}_{6}\right) \\
6.22\left(\mathrm{q}, \mathrm{H}_{5}\right) \\
6.93\left(\mathrm{q}, \mathrm{H}_{4}\right) \\
6.15\left(\mathrm{~d}, \mathrm{H}_{3}\right)\end{array}$ \\
\hline 5-SSAZr(p-CH $\left.\mathrm{CH}_{3} \mathrm{TPP}\right)$ & & $8.96(\mathrm{~s}, 8 \mathrm{H})$ & $\begin{array}{c}8.47\left(\mathrm{~s}, 4 \mathrm{H}, \mathrm{H}_{\mathrm{o}}\right) \\
8.18\left(\mathrm{~s}, 4 \mathrm{H}, \mathrm{H}_{\mathrm{o}}\right) \\
7.78\left(\mathrm{~m}, 8 \mathrm{H}, \mathrm{H}_{\mathrm{m}}\right) \\
2.85\left(\mathrm{~s}, 12 \mathrm{H}, \mathrm{H}_{\mathrm{CH}_{3}}\right)\end{array}$ & $\begin{array}{l}7.17\left(\mathrm{~s}, 1 \mathrm{H}, \mathrm{H}_{6}\right) \\
7.08\left(\mathrm{~d}, 1 \mathrm{H}, \mathrm{H}_{3}\right) \\
7.06\left(\mathrm{q}, 1 \mathrm{H}, \mathrm{H}_{4}\right)\end{array}$ \\
\hline p-ClTPP & $-2.75(\mathrm{~s}, 2 \mathrm{H})$ & $8.73(\mathrm{~s}, 8 \mathrm{H})$ & $\begin{array}{l}8.25\left(\mathrm{~s}, 4 \mathrm{H}, \mathrm{H}_{\mathrm{o}}\right) \\
7.75\left(\mathrm{~s}, 4 \mathrm{H}, \mathrm{H}_{\mathrm{p}}\right)\end{array}$ & - \\
\hline $\mathrm{Cl}_{2} \mathrm{Zr}(\mathrm{p}-\mathrm{ClTPP})$ & & $8.97(\mathrm{~s}, 8 \mathrm{H})$ & $\begin{array}{c}8.33\left(\mathrm{~d}, 4 \mathrm{H}, \mathrm{H}_{\mathrm{o}}\right) \\
8.13\left(\mathrm{~s}, 4 \mathrm{H}, \mathrm{H}_{\mathrm{o}}\right) \\
7.59\left(\mathrm{~s}, 8 \mathrm{H}, \mathrm{H}_{\mathrm{m}}\right)\end{array}$ & - \\
\hline SAZr(p-ClTPP) & & $9.12(\mathrm{~s}, 8 \mathrm{H})$ & $\begin{array}{c}8.42\left(\mathrm{~d}, 4 \mathrm{H}, \mathrm{H}_{\mathrm{o}}\right) \\
8.17\left(\mathrm{~m}, 4 \mathrm{H}, \mathrm{H}_{\mathrm{o}}\right) \\
8.02\left(\mathrm{~m}, 8 \mathrm{H}, \mathrm{H}_{\mathrm{m}}\right)\end{array}$ & $\begin{array}{l}6.16\left(\mathrm{~d}, \mathrm{H}_{6}\right) \\
6.30\left(\mathrm{q}, \mathrm{H}_{5}\right) \\
6.98\left(\mathrm{q}, \mathrm{H}_{4}\right) \\
6.26\left(\mathrm{~d}, \mathrm{H}_{3}\right) \\
\end{array}$ \\
\hline 5-SSAZr(p-ClTPP) & & $9.25(\mathrm{~s}, 8 \mathrm{H})$ & $\begin{array}{l}8.46\left(\mathrm{~s}, 4 \mathrm{H}, \mathrm{H}_{\mathrm{o}}\right) \\
8.23\left(\mathrm{~s}, 4 \mathrm{H}, \mathrm{H}_{\mathrm{o}}\right) \\
8.09\left(\mathrm{~s}, 8 \mathrm{H}, \mathrm{H}_{\mathrm{m}}\right)\end{array}$ & $\begin{array}{l}7.20\left(\mathrm{~s}, 1 \mathrm{H}, \mathrm{H}_{6}\right) \\
7.15\left(\mathrm{~d}, 1 \mathrm{H}, \mathrm{H}_{3}\right) \\
7.09\left(\mathrm{q}, 1 \mathrm{H}, \mathrm{H}_{4}\right)\end{array}$ \\
\hline $\mathrm{p}-\mathrm{NO}_{2} \mathrm{TPP}$ & $-2.84(\mathrm{~s}, 2 \mathrm{H})$ & $8.83(\mathrm{~s}, 8 \mathrm{H})$ & $\begin{array}{l}8.68\left(\mathrm{~s}, 8 \mathrm{H}, \mathrm{H}_{\mathrm{o}}\right) \\
8.41\left(\mathrm{~s}, 8 \mathrm{H}, \mathrm{H}_{\mathrm{m}}\right)\end{array}$ & - \\
\hline $\mathrm{Cl}_{2} \mathrm{Zr}\left(\mathrm{p}-\mathrm{NO}_{2} \mathrm{TPP}\right)$ & & $9.05(\mathrm{~s}, 8 \mathrm{H})$ & $\begin{array}{l}8.42\left(\mathrm{~d}, 4 \mathrm{H}, \mathrm{H}_{\mathrm{o}}\right) \\
8.04\left(\mathrm{~d}, 4 \mathrm{H}, \mathrm{H}_{\mathrm{o}}\right) \\
7.79\left(\mathrm{~s}, 8 \mathrm{H}, \mathrm{H}_{\mathrm{m}}\right)\end{array}$ & - \\
\hline $\mathrm{SAZr}\left(\mathrm{p}-\mathrm{NO}_{2} \mathrm{TPP}\right)$ & & $9.17(\mathrm{~s}, 8 \mathrm{H})$ & $\begin{array}{l}8.42\left(\mathrm{~s}, 4 \mathrm{H}, \mathrm{H}_{\mathrm{o}}\right) \\
8.07\left(\mathrm{~d}, 4 \mathrm{H}, \mathrm{H}_{\mathrm{o}}\right) \\
7.64\left(\mathrm{~s}, 8 \mathrm{H}, \mathrm{H}_{\mathrm{m}}\right)\end{array}$ & $\begin{array}{l}6.18\left(\mathrm{~d}, \mathrm{H}_{6}\right) \\
6.55\left(\mathrm{q}, \mathrm{H}_{5}\right) \\
7.05\left(\mathrm{q}, \mathrm{H}_{4}\right) \\
6.52\left(\mathrm{~d}, \mathrm{H}_{3}\right)\end{array}$ \\
\hline 5-SSAZr(p-NO $\left.{ }_{2} \mathrm{TPP}\right)$ & & $9.26(\mathrm{~s}, 8 \mathrm{H})$ & $\begin{array}{c}8.45\left(\mathrm{~s}, 4 \mathrm{H}, \mathrm{H}_{\mathrm{o}}\right) \\
8.11\left(\mathrm{~s}, 4 \mathrm{H}, \mathrm{H}_{\mathrm{o}}\right) \\
7.65\left(\mathrm{~s}, 8 \mathrm{H}, \mathrm{H}_{\mathrm{m}}\right)\end{array}$ & $\begin{array}{l}7.92\left(\mathrm{~s}, 1 \mathrm{H}, \mathrm{H}_{6}\right) \\
7.78\left(\mathrm{~d}, 1 \mathrm{H}, \mathrm{H}_{3}\right) \\
7.23\left(\mathrm{q}, 1 \mathrm{H}, \mathrm{H}_{4}\right)\end{array}$ \\
\hline
\end{tabular}



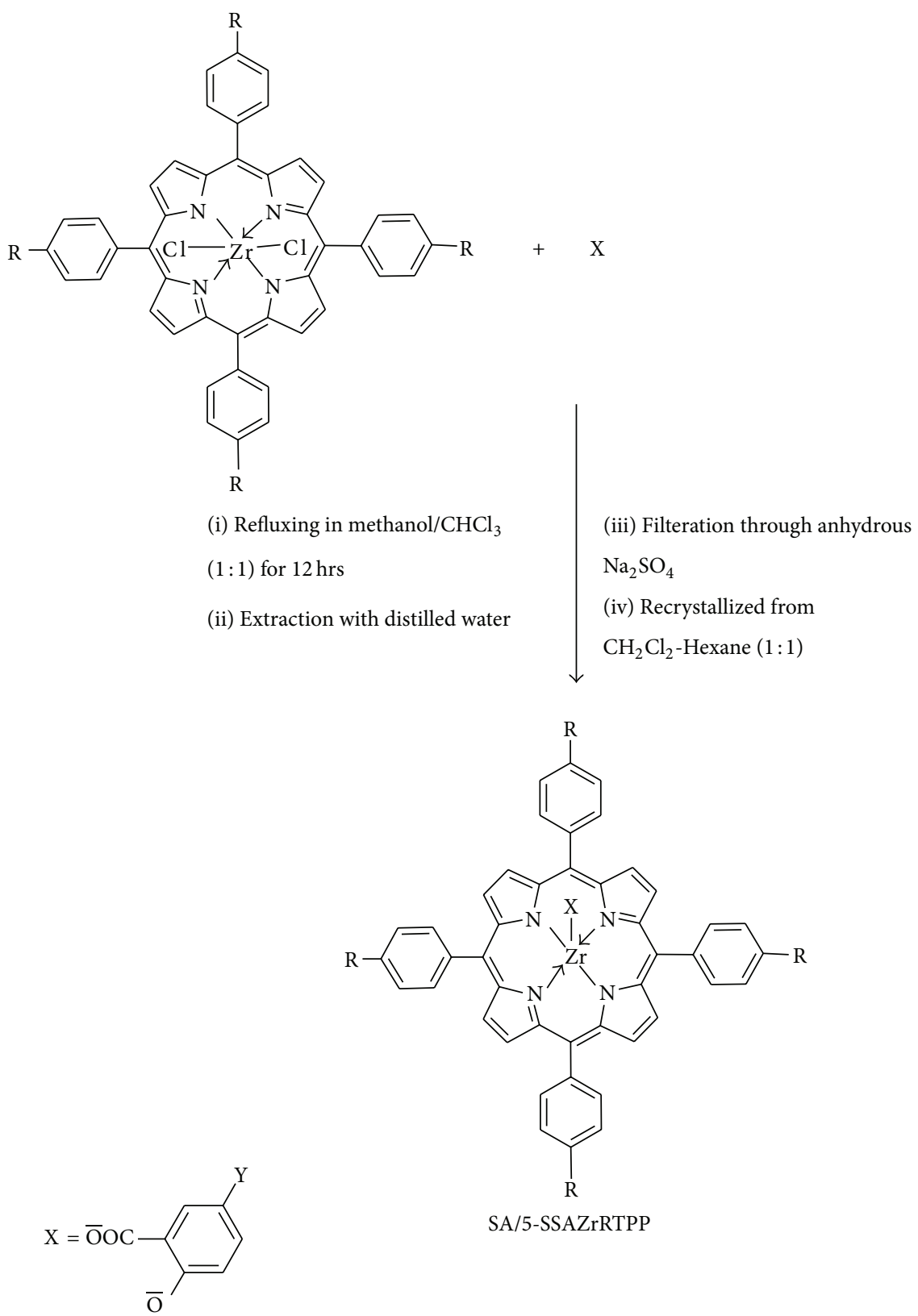

$\mathrm{Y}($ axial ligand $)=\mathrm{H}$, salicylate $(\mathrm{SA})$

$\mathrm{Y}($ axial ligand $)=\mathrm{SO}_{3} \mathrm{H}, 5$-sulfosalicylate (5-SSA)

SCHeme 3: General synthetic route for the synthesis of axially ligated $\operatorname{Zr}(\mathrm{IV})$ porphyrins complexes.

molecular ions. This fact can be explained by the coordinated unsaturation of zirconium atom [22].

In the present investigation, the variations of emission properties in free base porphyrin $\mathrm{p}-\mathrm{CH}_{3} \mathrm{TPP}$ and its corresponding metallated and axially ligated $\mathrm{Zr}(\mathrm{IV})$ porphyrins have been studied (Table 5). The freebase porphyrins exhibit two emission bands at 653 and $715 \mathrm{~nm}$ corresponding to $\mathrm{Q}(0,0)$ and $\mathrm{Q}(0,1)$ transitions, respectively, the intensity of the $\mathrm{Q}(0,0)$ being higher than the $\mathrm{Q}(0,1)$ transition.
TABLE 5: Summary of the fluorescence band maxima at $23 \mathrm{~K}$ in DMSO.

\begin{tabular}{lccc}
\hline Compound & \multicolumn{3}{c}{$\lambda_{\text {max }}, \mathrm{nm}$} \\
$\mathrm{Q}(0,0)$ & $\mathrm{Q}(0,0)$ & $\mathrm{Q}(0,1)$ \\
\hline $\mathrm{p}-\mathrm{CH}_{3} \mathrm{TPP}$ & 450 & 653 & 715 \\
$\mathrm{Cl}_{2} \mathrm{Zr}\left(\mathrm{p}-\mathrm{CH}_{3} \mathrm{TPP}\right)$ & 441 & - & 653 \\
$\mathrm{SAZr}\left(\mathrm{p}-\mathrm{CH}_{3} \mathrm{TPP}\right)$ & 440 & 609 & 660 \\
5-SSAZr(p-CH $\mathrm{TPP})$ & 440 & 608 & 657 \\
\hline
\end{tabular}




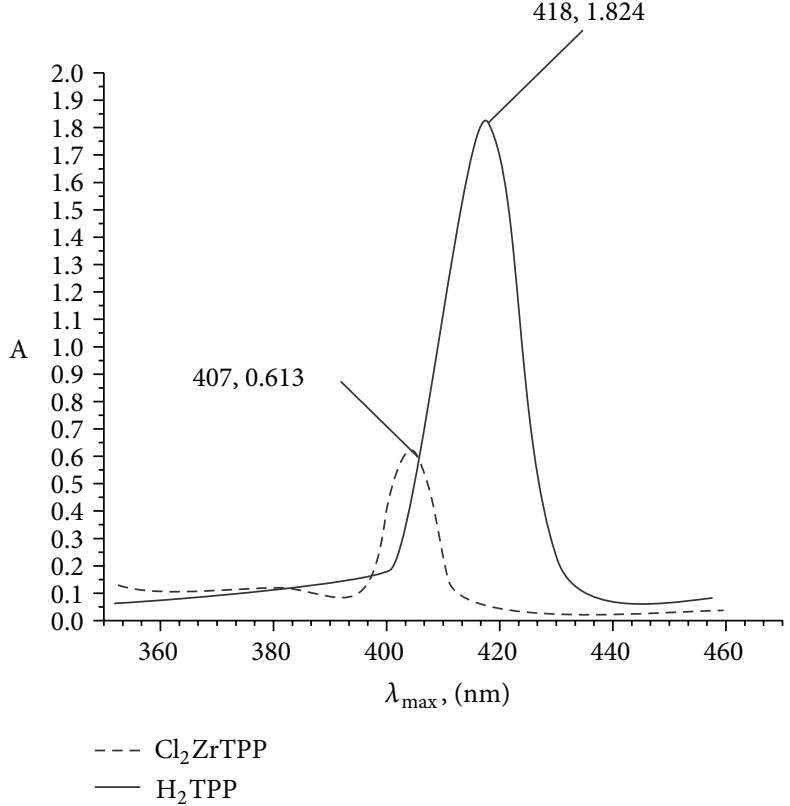

(a)

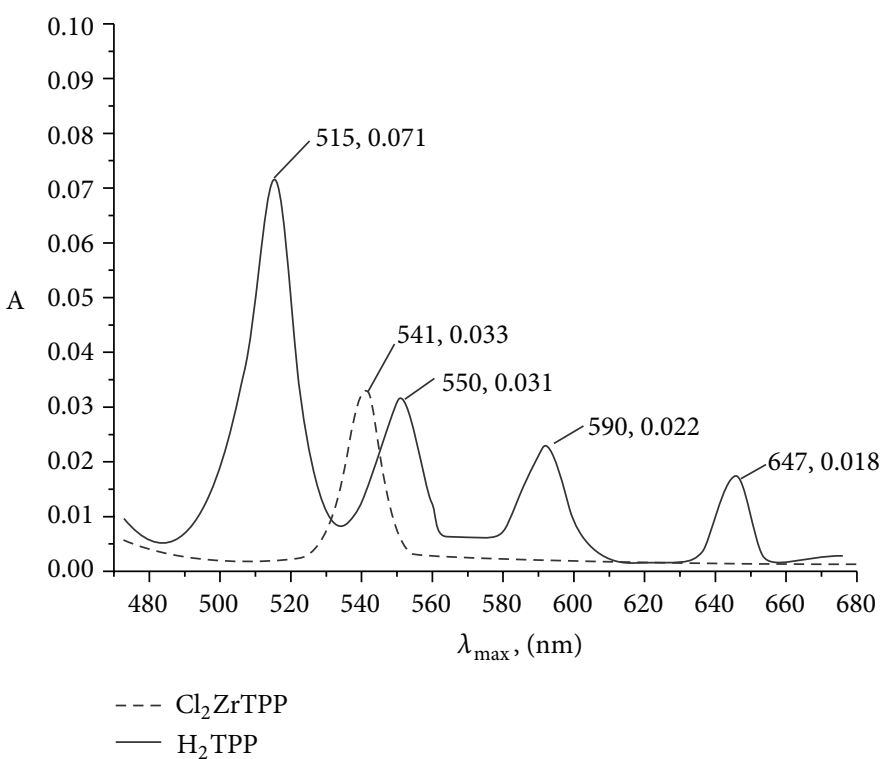

(b)

Figure 1: UV-Vis overlapped (a) B bands (b) Q bands of TPP and $(\mathrm{Cl})_{2}$ ZrTPP in chloroform.

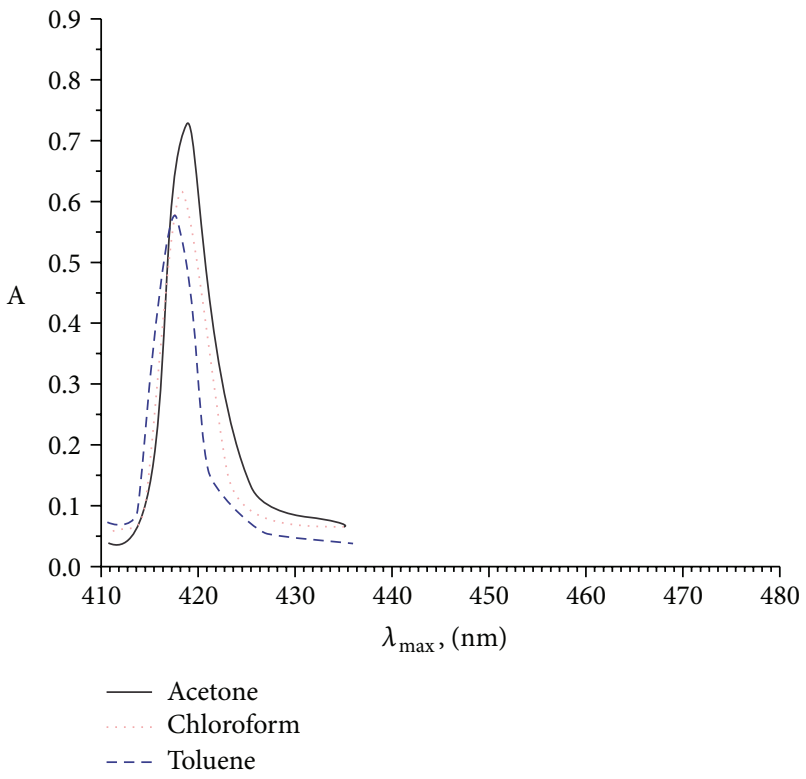

(a)

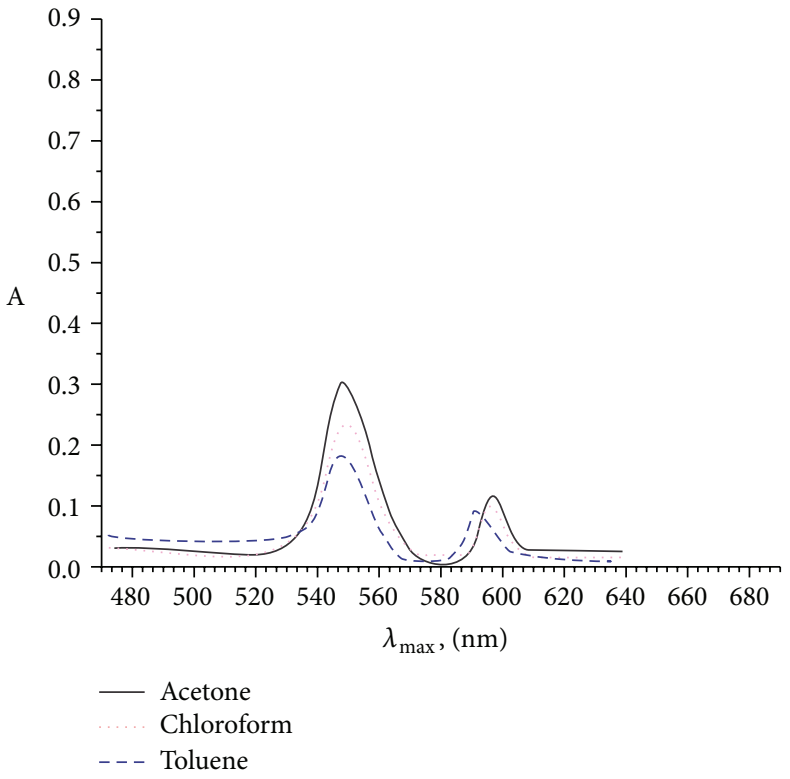

(b)

FIGURE 2: UV-vis spectra of SAZrTPP (a) B bands (b) Q bands in different solvents.

The complexes $\mathrm{Cl}_{2} \mathrm{Zr}\left(\mathrm{p}-\mathrm{CH}_{3} \mathrm{TPP}\right)$, SAZr(p- $\left.\mathrm{CH}_{3} \mathrm{TPP}\right)$, and 5$\operatorname{SSAZr}\left(\mathrm{p}-\mathrm{CH}_{3} \mathrm{TPP}\right)$ are emissive and show intraligand fluorescence comparable to other regular metalloporphyrins with maxima occurring at 653, 660, and $657 \mathrm{~nm}$, respectively. However, the emission bands of axially ligated $\mathrm{Zr}(\mathrm{IV})$ porphyrins are blue shifted compared to free base porphyrins. This behavior is attributed to an enhanced spin-orbit coupling induced by the presence of the heavy-atom central metals in zirconium(IV) porphyrins complexes, which leads to a more efficient intersystem crossing from the lowest porphyrin singlet excited state ${ }^{1} S_{1}\left(\pi, \pi^{*}\right)$ to the corresponding triplet manifold and thus reduces the probability of fluorescent emission [35]. Thus, the excitation spectrum of fluorescence is in agreement with absorption spectrum (Figure 3).

Cyclic voltammetric studies have been carried out for $\mathrm{Cl}_{2} \mathrm{Zr}\left(\mathrm{p}-\mathrm{CH}_{3} \mathrm{TPP}\right)$ and its salicylate and 5-sulfosalicylate 


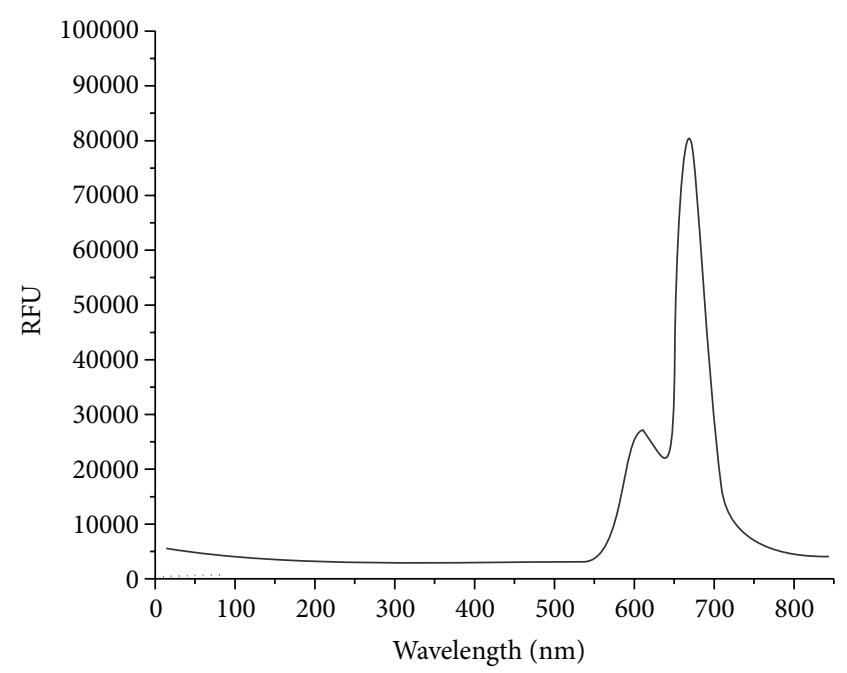

(a)

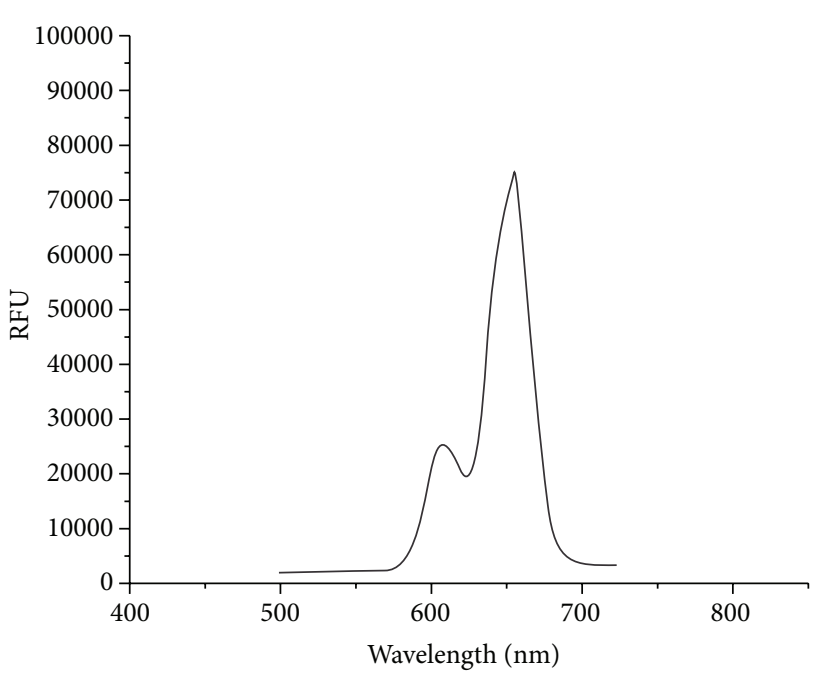

(b)

FIGURE 3: $\mathrm{S}_{1} \rightarrow \mathrm{S}_{0}$ fluorescence spectrum of (a) SAZr (p-CH $\left.\mathrm{CPP}\right)$ and (b) 5-SSAZr $\left(\mathrm{p}-\mathrm{CH}_{3} \mathrm{TPP}\right)$ in DMSO $\left(\mathrm{C}=10^{-6} \mathrm{~mol} \mathrm{~L}^{-1}, \lambda_{\text {exc }}=420 \mathrm{~nm}\right)$.

TABLE 6: Electrochemical data for synthesized $\mathrm{Cl}_{2} \mathrm{Zr}\left(\mathrm{p}-\mathrm{CH}_{3} \mathrm{TPP}\right), \mathrm{SAZr}\left(\mathrm{p}-\mathrm{CH}_{3} \mathrm{TPP}\right)$, and 5-SSAZr $\left(\mathrm{p}-\mathrm{CH}_{3} \mathrm{TPP}\right)$ complexes in dichloromethane.

\begin{tabular}{lcccc}
\hline Species & $E_{\mathrm{OX} 2} / \mathrm{V}$ & $E_{\mathrm{OX1}} / \mathrm{V}$ & $E_{\text {red1 }} / \mathrm{V}$ & $\Delta E \mathrm{~d} / \mathrm{V}$ \\
\hline $\mathrm{Cl}_{2} \mathrm{Zr}\left(4-\mathrm{CH}_{3} \mathrm{TPP}\right)$ & 1.22 & 0.66 & 1.30 & 1.88 \\
$\mathrm{SAZr}\left(4-\mathrm{CH}_{3} \mathrm{TPP}\right)$ & 1.25 & 0.68 & 1.22 & 1.93 \\
$5-\mathrm{SSAZr}\left(4-\mathrm{CH}_{3} \mathrm{TPP}\right)$ & 1.28 & 0.70 & 1.15 & 1.98 \\
\hline
\end{tabular}

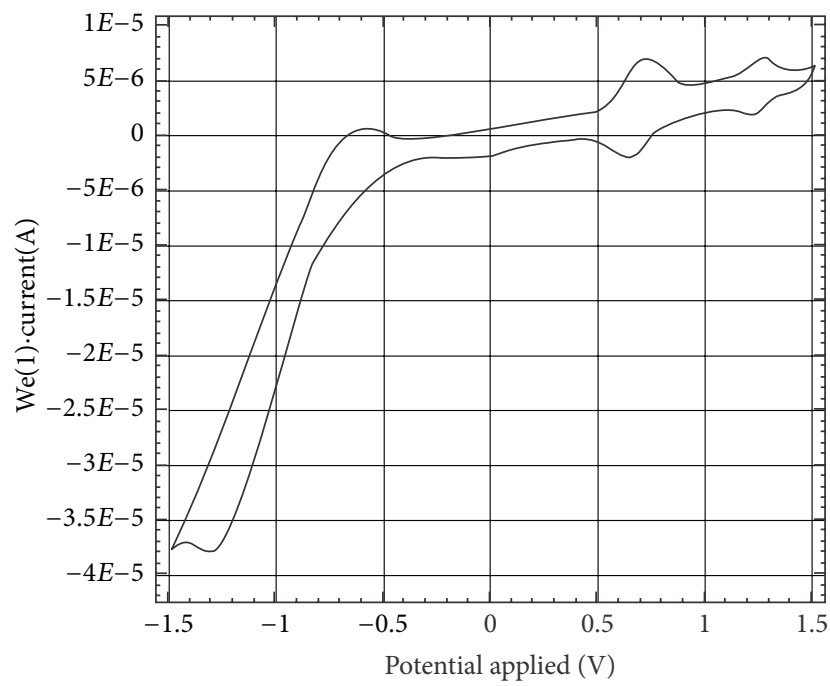

FIGURE 4: Cyclic voltammogram of $\mathrm{Zr}\left(\mathrm{p}-\mathrm{CH}_{3} \mathrm{TPP}\right)$ in $\mathrm{CH}_{2} \mathrm{Cl}_{2}$ containing $0.1 \mathrm{M}$ (TBA) $\mathrm{PF}_{6}$. Scan rate $20 \mathrm{mV} / \mathrm{s}$.

ligated $\mathrm{Zr}(\mathrm{IV})$ derivatives to elucidate the effects of the peripheral substituents on the electrochemical redox potentials (Table 6). The electrochemical redox processes of the porphyrin and their metallated derivatives arise primarily from the $\pi$ electron system of the macrocycle. Figure 4 shows the cyclic voltammogram of $\mathrm{Cl}_{2} \mathrm{Zr}\left(\mathrm{p}-\mathrm{CH}_{3} \mathrm{TPP}\right)$ in $\mathrm{CH}_{2} \mathrm{Cl}_{2}$. In the oxidative scan, two redox couples were observed at 0.66 and $1.22 \mathrm{~V}$ corresponding to the formation of porphyrin cation radical and porphyrin dication, respectively. There is a wave in the reductive scan at $1.30 \mathrm{~V}$. The wave is characteristic of one electron reduction of the macrocycle. The data clearly demonstrated the formation of the porphyrin radical anion and inability to reduce $\mathrm{Zr}(\mathrm{IV})$ metal centre [36].

For the investigated salicylate ligated zirconium(IV) porphyrins, we observed one reversible reduction wave and two reversible oxidation waves. The three waves for the complexes (Table 6) can be attributed to one-electron processes $\mathrm{ZrT}\left(\mathrm{p}-\mathrm{CH}_{3}\right) \mathrm{PPX}^{0 /-1}, \mathrm{ZrT}\left(\mathrm{p}-\mathrm{CH}_{3}\right) \mathrm{PPX}^{1+/ 0}$, and $\mathrm{ZrT}\left(\mathrm{p}-\mathrm{CH}_{3}\right) \mathrm{PPX}^{2+/+1}(\mathrm{X}=\mathrm{SA}, 5-\mathrm{SA})$, respectively, corresponding to the one-electron oxidation/reduction processes involving not only the porphyrin ring but also the entire system as a whole, including even the conjugated salicylate/5sulfosalicylate ligand [37].

The central metal atom (zirconium), being electrochemically passive [38], plays the role of a "linkage" connecting theconjugated systems into a whole integral. The zirconium(IV) porphyrin HOMO-LUMO gap can be expressed as $\Delta E$, the potential difference between the first oxidation and the first reduction. The differences between the potentials of the first oxidation wave and the first reduction wave $\left(E_{\text {oxl }}-E_{\text {red1 }}\right)$ are $1.93 \mathrm{~V}$ and $1.98 \mathrm{~V}$ for SAZr(p- $\left.\mathrm{CH}_{3} \mathrm{TPP}\right)$ and 5-SSAZr(p$\mathrm{CH}_{3} \mathrm{TPP}$ ), respectively, allow us to assign these waves to oxidation/reduction processes involving the macrocyclic ring. The experimental $\Delta E$ values of substituted zirconium(IV) porphyrins are in the range of $1.88-1.98 \mathrm{~V}$.

Thermal analysis of SAZrTPP is shown in Figure 5. The TG curve of SAZrTPP (Figure 5) shows a continuous weight 


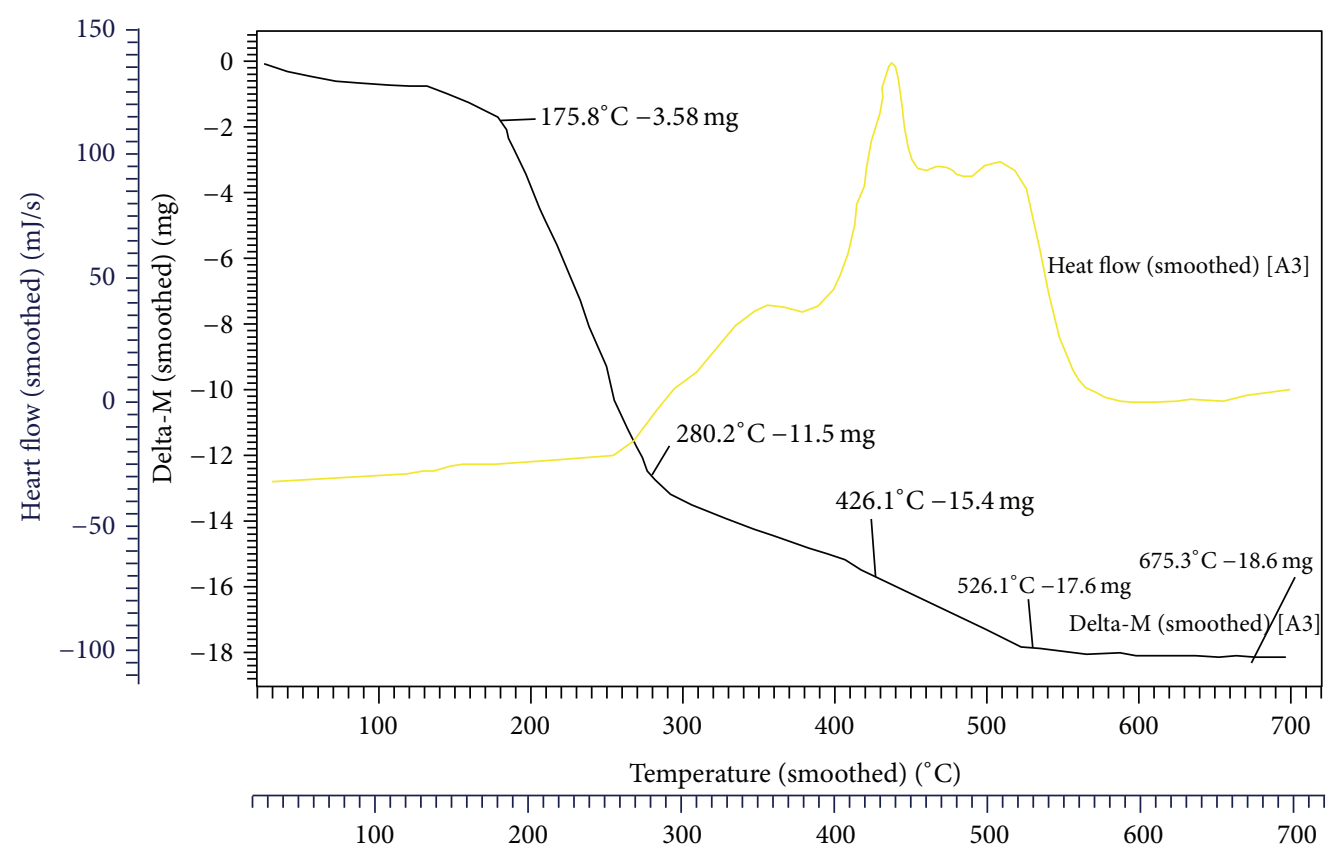

Figure 5: TGA (black line) and DTA (yellow line) picture of SAZrTPP.

TABLE 7: In vitro antibacterial evaluation of free base porphyrin and the corresponding zirconium(IV) porphyrin complexes.

\begin{tabular}{|c|c|c|c|c|c|}
\hline Porphyrin $(100 \mu \mathrm{g} / \mathrm{mL})$ & B. subtilis & S. aureus & M. luteus & E. coli & P. fluorescens \\
\hline TPP & - & - & - & - & - \\
\hline $\mathrm{Cl}_{2} \mathrm{ZrTPP}$ & - & - & - & 7 & - \\
\hline SAZrTPP & - & - & - & 14 & - \\
\hline 5-SSAZrTPP & - & - & - & - & - \\
\hline $\mathrm{p}-\mathrm{CH}_{3} \mathrm{TPP}$ & - & - & - & 6 & - \\
\hline $\mathrm{Cl}_{2} \mathrm{Zr}\left(\mathrm{p}-\mathrm{CH}_{3} \mathrm{TPP}\right)$ & - & - & - & 11 & - \\
\hline $\mathrm{SAZr}\left(\mathrm{p}-\mathrm{CH}_{3} \mathrm{TPP}\right)$ & 6 & - & 7 & - & - \\
\hline 5-SSAZr $\left(\mathrm{p}-\mathrm{CH}_{3} \mathrm{TPP}\right)$ & - & - & - & 9 & - \\
\hline$\left(\mathrm{p}-\mathrm{NO}_{2} \mathrm{TPP}\right)$ & - & - & - & - & - \\
\hline $\mathrm{Cl}_{2} \mathrm{Zr}\left(\mathrm{p}-\mathrm{NO}_{2} \mathrm{TPP}\right)$ & - & - & - & - & - \\
\hline $\mathrm{SAZr}\left(\mathrm{p}-\mathrm{NO}_{2} \mathrm{TPP}\right)$ & - & - & - & - & - \\
\hline 5-SSAZr(p-NO $\left.{ }_{2} \mathrm{TPP}\right)$ & 10 & 11 & 15 & 13 & 11 \\
\hline Control chloramphenicol $(10 \mu \mathrm{g})$ & 16 & 12 & 18 & 14 & 9 \\
\hline
\end{tabular}

loss starting from $150^{\circ} \mathrm{C}$ to $700^{\circ} \mathrm{C}$, when a stable oxide of $\mathrm{ZrO}_{2}$ is formed. The initial weight loss of about $16.37 \%$ observed between $140^{\circ} \mathrm{C}$ and $175.8^{\circ} \mathrm{C}$ is attributed to the loss of salicylate group (the theoretical value $=16.32 \%$ ). In the range of 200 to $280.2^{\circ} \mathrm{C}$, up to $52.58 \%$ of the mass had been lost due to the loss of tetraphenyl groups (the theoretical value $=$ $53.04 \%$ ). At $426.1^{\circ} \mathrm{C}$, up to $70.41 \%$ (the theoretical value $=$ $69.01 \%$ ) of the total mass had been lost which is attributed to the collapse of macrocyclic ligand; correspondingly, there is a large exothermic peak in DTA curve. The organic moiety decomposes further with increasing temperature. Further in the range $425-526.2^{\circ} \mathrm{C}$, the weight loss reaches up to $80.47 \%$ which is attributed to the removal of pyrrole fragments. At $675.3^{\circ} \mathrm{C}$ the evident weight loss of $85.04 \%$ is due to the complete decomposition of SAZrTPP leaving behind stable zirconium oxide (the theoretical value $=85.33 \%$ ). Simultaneously, there are some exothermal peaks in the range of $340-530^{\circ} \mathrm{C}$ on the DTA curve showing major weight loss in the region. The small exothermic peaks correspond to the loss of chains of the porphyrin ring and the large exothermic peak corresponds to the collapse of the porphyrin skeleton. The thermogravimetric analysis of the complex showed that zirconium(IV) porphyrin complex is stable up to approximately $150^{\circ} \mathrm{C}$.

3.1.2. Biological Studies. The ability of porphyrins to accumulate in malignant tumors has led to the application of these compounds in diagnosis and treatment of these malignant neoplasms. In the present research work, some complexes were evaluated for antibacterial and anticancer activity. Antibacterial activity of the synthesized zirconium(IV) porphyrin complexes was tested by Agar well-diffusion method (Table 7). The free base porphyrin and their corresponding metallated and axially ligated zirconium(IV) 
Effect of axially ligated zirconium porphyrin on human cancer cell lines

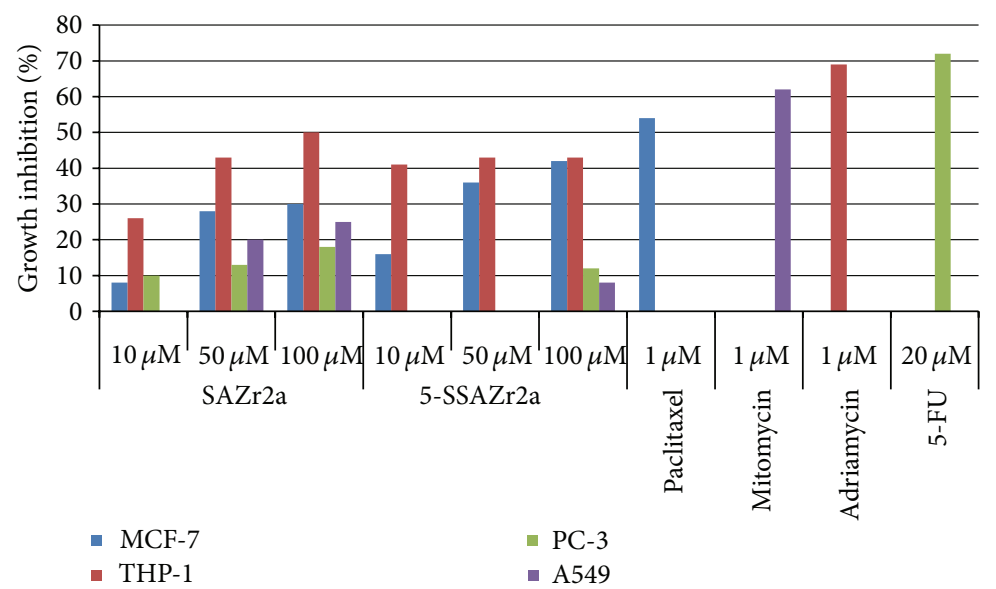

FIGURE 6: Cytotoxicity of SAZr $\left(\mathrm{p}-\mathrm{CH}_{3} \mathrm{TPP}\right)$ and 5-SSAZr $\left(\mathrm{p}-\mathrm{CH}_{3} \mathrm{TPP}\right)$, where $2 \mathrm{a}=\mathrm{p}-\mathrm{CH}_{3} \mathrm{TPP}$.

porphyrin complexes, namely, TPP, p- $\mathrm{CH}_{3} \mathrm{TPP}, \mathrm{p}-\mathrm{NO}_{2} \mathrm{TPP}$, $\mathrm{Cl}_{2} \mathrm{ZrTPP}, \mathrm{Cl}_{2} \mathrm{Zr}\left(\mathrm{p}-\mathrm{CH}_{3} \mathrm{TPP}\right), \mathrm{Cl}_{2} \mathrm{Zr}\left(\mathrm{p}-\mathrm{NO}_{2} \mathrm{TPP}\right)$, SAZrTPP, 5-SSAZrTPP, SAZr(p-CH $\left.\mathrm{CH}_{3} \mathrm{TP}\right), \quad$ 5-SSAZr $\left(\mathrm{p}-\mathrm{CH}_{3} \mathrm{TPP}\right)$, $\mathrm{SAZr}\left(\mathrm{p}-\mathrm{NO}_{2} \mathrm{TPP}\right)$, and 5-SSAZr $\left(\mathrm{p}-\mathrm{NO}_{2} \mathrm{TPP}\right)$ were tested at the concentration of $100 \mu \mathrm{g} / \mathrm{mL}$ against five bacterial strains, namely, Bacillus subtilis, Micrococcus luteus, Staphylococcus aureus, Pseudomonas fluorescens, and Escherichia coli. Our results demonstrated antibacterial activity against most of the zirconium(IV) porphyrin complexes. Among all the complexes prepared, 5-SSAZr $\left(\mathrm{p}-\mathrm{NO}_{2} \mathrm{TPP}\right)$ was found to be highly potential against all the five bacterial strains with sensitivity ranging from 10 to $15 \mathrm{~mm}$ zone of inhibition at $100 \mu \mathrm{g} / \mathrm{mL}$, respectively (Table 7). SAZr $\left(\mathrm{p}-\mathrm{CH}_{3} \mathrm{TPP}\right.$ ) complex showed sensitivity only against $B$. subtilis and $M$. luteus with zones of inhibition of 6 and $7 \mathrm{~mm}$, respectively, and it was the only other complex after 5-SSAZr(p-NO $\mathrm{NPP}_{2}$ complex that showed antibacterial sensitivity against gram positive bacteria (B. subtilis). Other complexes, namely, $\mathrm{Cl}_{2} \mathrm{ZrTPP}$, SAZrTPP, p- $\mathrm{CH}_{3} \mathrm{TPP}, \mathrm{Cl}_{2} \mathrm{Zr}\left(\mathrm{p}-\mathrm{CH}_{3} \mathrm{TPP}\right)$, and 5-SSAZr $\left(\mathrm{p}-\mathrm{CH}_{3} \mathrm{TPP}\right)$ showed sensitivity only against gram negative bacteria $E$. coli with zones of inhibition ranging from 6 to $14 \mathrm{~mm}$, respectively. The rest of the complexes did not show any sensitivity against any bacterial strain used in the studies (Table 7).

3.1.3. In Vitro Cytotoxicity. The cytotoxicity of SAZr(p$\left.\mathrm{CH}_{3} \mathrm{TPP}\right)$ and 5-SSAZr(p-CH $\left.\mathrm{CH}_{3} \mathrm{TPP}\right)$ was evaluated against four human cancer cell lines, namely, breast (MCF-7), leukemia (THP-1), prostate (PC-3), and lung (A549) at different concentrations as shown in Figure 6. It was observed that both compounds showed less than $50 \%$ growth inhibition.

\section{Conclusion}

In this paper, we have described the synthesis of pure porphyrins and their subsequent reactions with $\mathrm{ZrCl}_{4}$ and salicylic acid/5-sulfosalicylic acid so as to get their axially ligated $\mathrm{Zr}(\mathrm{IV})$ porphyrins. The structures of above porphyrin compounds were characterized by UV-vis, IR, ${ }^{1} \mathrm{H}$ NMR,

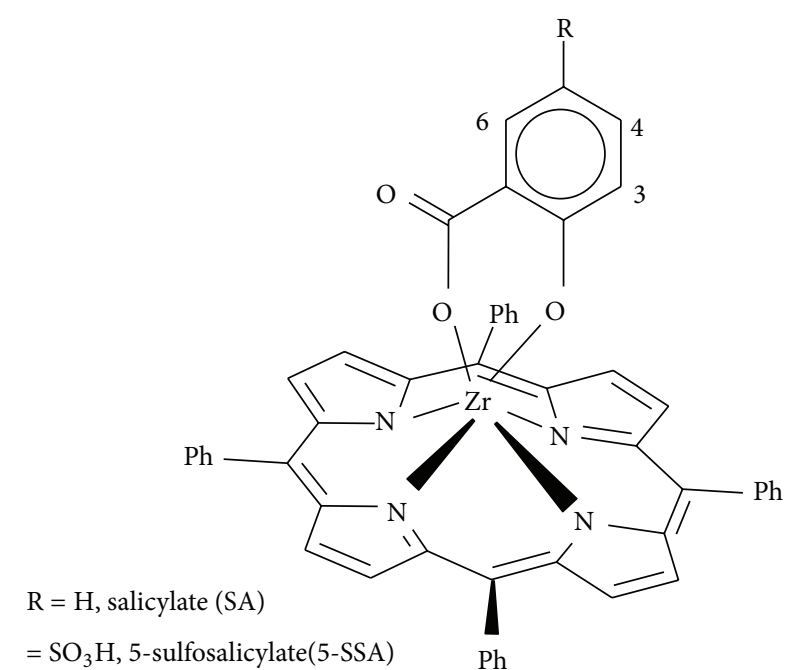

FIGURE 7: Proposed structure for axially ligated zirconium(IV) porphyrin complexes.

and elemental analysis. In axially ligated zirconium(IV) porphyrin complexes, bands showed slight red shift corresponding to the structural distortion in the porphyrin macrocycle and concomitant electronic coupling of the metalloporphyrin to the salicylate mediated by the zirconium metal ion. The infrared spectra of these compounds showed that salicylate groups axially ligated to zirconium(IV) porphyrins to form six-coordinate complexes of $\mathrm{Zr}(\mathrm{IV})$ porphyrins (Figure 7). Additionally, the ${ }^{1} \mathrm{H}$ NMR spectral study of these compounds showed that signals of axial salicylic and 5-sulfosalicylic fragment protons are shifted to higher field in comparison to the signals of porphyrin protons and also in comparison to proton signals of free salicylic and/or 5-sulfosalicylic acids respectively. The ESI mass spectroscopy provided the information regarding the appearance of the molecular ion peak $(m / z)$ and specific fragmentation. Meanwhile, 
cyclic voltammograms of axially ligated zirconium(IV) porphyrins complexes have shown three waves for the studied complexes which can be attributed to one-electron processes $\mathrm{M}\left(4-\mathrm{CH}_{3} \mathrm{TPP}\right) \mathrm{X}^{0 /-1}, \mathrm{M}\left(4-\mathrm{CH}_{3} \mathrm{TPP}\right) \mathrm{X}^{1+/ 0}$, and $\mathrm{M}(4-$ $\left.\mathrm{CH}_{3} \mathrm{TPP}\right) \mathrm{X}^{2+/+1}(\mathrm{X}=\mathrm{SA}, 5-\mathrm{SA} ; \mathrm{M}=\mathrm{Zr})$. All these complexes exhibit reversible oxidation and reduction potentials characteristic of the porphyrin. The data of thermogravimetric analysis indicated that the zirconium(IV) porphyrins complexes are stable up to approximately $150^{\circ} \mathrm{C}$. Their possible biological activities were also investigated and most of the samples exhibited moderate antimicrobial activity against test microorganisms. The two complexes screening for anticancer activity showed less than $50 \%$ growth inhibition.

\section{References}

[1] Z. Xue, P. P. S. Lee, Y. Wang et al., "Further insight into aryl nitration of tetraphenylporphyrin," Tetrahedron, vol. 67, no. 33, pp. 6030-6035, 2011.

[2] Y. Xu, Z. Liu, X. Zhang et al., "A graphene hybrid material covalently functionalized with porphyrin: synthesis and optical limiting property," Advanced Materials, vol. 21, no. 12, pp. 12751279, 2009.

[3] C. D. Natale, D. Monti, and R. Paolesse, "Chemical sensitivity of porphyrin assemblies," Materials Today, vol. 13, no. 7-8, pp. 46$52,2010$.

[4] M. Wathier and M. W. Grinstaff, "Synthesis and properties of supramolecular ionic networks," Journal of the American Chemical Society, vol. 130, no. 30, pp. 9648-9649, 2008.

[5] C. M. Drain, A. Varotto, and I. Radivojevic, "Self-organized porphyrinic materials," Chemical Reviews, vol. 109, no. 5, pp. 1630$1658,2009$.

[6] M. Endo, M. Fujitsuka, and T. Majima, "Diastereochemically controlled porphyrin dimer formation on a DNA duplex scaffold," Journal of Organic Chemistry, vol. 73, no. 3, pp. 1106-1112, 2008.

[7] B. Meunier, "Metalloporphyrins as versatile catalysts for oxidation reactions and oxidative DNA cleavage," Chemical Reviews, vol. 92, no. 6, pp. 1411-1456, 1992.

[8] B. Gao, Y. Chen, and Q. Lei, "Hydroxylation of cyclohexane with molecular oxygen catalyzed by highly efficient heterogeneous $\mathrm{Mn}$ (III) porphyrin catalysts prepared by special synthesis and immobilization method," Journal of Inclusion Phenomena and Macrocyclic Chemistry, vol. 74, no. 1-4, pp. 455-465, 2012.

[9] A. E. O'Connor, W. M. Gallagher, and A. T. Byrne, "Porphyrin and nonporphyrin photosensitizers in oncology: preclinical and clinical advances in photodynamic therapy," Photochemistry and Photobiology, vol. 85, no. 5, pp. 1053-1074, 2009.

[10] D. Vlascici, E. F. Cosma, E. M. Pica et al., "Free base porphyrins as ionophores for heavy metal sensors," Sensors, vol. 8, no. 8, pp. 4995-5004, 2008.

[11] Y. Ni, "Metalloporphyrins and functional analogues as MRI contrast agents," Current Medical Imaging Reviews, vol. 4, no. 2, pp. 96-112, 2008.

[12] A. A. Fadda, R. E. El-Mekawy, A. El-Shafei, H. S. Freeman, D. Hinks, and M. El-Fedawy, "Design, synthesis, and pharmacological screening of novel porphyrin derivatives," Journal of Chemistry, vol. 2013, Article ID 340230, 11 pages, 2013.

[13] N. A. Antonova, V. P. Osipova, M. N. Kolyada, N. O. Movchan, E. R. Milaeva, and Y. T. Pimenov, "Study of the antioxidant properties of porphyrins and their complexes with metals," Macroheterocycles, vol. 3, no. 2-3, pp. 139-144, 2010.

[14] M. Yuasa, K. Oyaizu, H. Murata, Y. Sahara, T. Hatsugai, and A. Ogata, "Antioxidant and anticancer properties of metalloporphyrins embedded in liposomes," Journal of Oleo Science, vol. 56, no. 2, pp. 87-93, 2007.

[15] I. Stojiljkovic, B. D. Evavold, and V. Kumar, "Antimicrobial properties of porphyrins," Expert Opinion on Investigational Drugs, vol. 10, no. 2, pp. 309-320, 2001.

[16] K. Rajesh, A. K. Rahiman, K. S. Bharathi, S. Sreedaran, V. Gangadevi, and V. Narayanan, "Spectroscopic, redox and biological studies of push-pull porphyrins and their metal complees," Bulletin of the Korean Chemical Society, vol. 31, no. 9, pp. 26562664, 2010.

[17] J. Bozja, J. Sherrill, S. Michielsen, and I. Stojiljkovic, "Porphyrinbased, light-activated antimicrobial materials," Journal of Polymer Science A, vol. 41, no. 15, pp. 2297-2303, 2003.

[18] A. Falber, B. P. Burton-Pye, I. Radivojevic et al., "Ternary porphyrinato HfIV and ZrIV polyoxometalate complexes," European Journal of Inorganic Chemistry, vol. 2009, no. 17, pp. 2459-2466, 2009.

[19] I. N. Tretyakova, V. Y. Chernii, L. A. Tomachynski, and S. V. Volkov, "Synthesis and luminescent properties of new zirconium(IV) and hafnium(IV) phthalocyanines with various carbonic acids as out-planed ligands," Dyes and Pigments, vol. 75, no. 1, pp. 67-72, 2007.

[20] L. A. Tomachynski, V. Y. Chernii, H. N. Gorbenko, V. V. Filonenko, and S. V. Volkov, "Synthesis, spectral properties, and antitumor activity of a new axially substituted phthalocyanine complex of zirconium(IV) with citric acid," Chemistry \& Biodiversity, vol. 1, no. 6, pp. 862-867, 2004.

[21] V. Kovalska, M. Losytskyy, V. Chernii et al., "Studies of antifibrillogenic activity of phthalocyanines of zirconium containing out-of-plane ligands," Bioorganic and Medicinal Chemistry, vol. 20, no. 1, pp. 330-334, 2012.

[22] Y. S. Gerasymchuk, V. Y. Chernii, L. A. Tomachynskii, M. Kowalska, J. Legendziewicz, and S. Radzki, "Correlation between computer models of structure of 5-sulfosalicylato $\mathrm{Zr}(\mathrm{IV})$ phthalocyanine with results obtained by NMR, ESI-MS and UV-Vis spectra," Optical Materials, vol. 32, no. 9, pp. 11931201, 2010.

[23] F. Oke, B. Aslim, S. Ozturk, and S. Altundag, "Essential oil composition, antimicrobial and antioxidant activities of Satureja cuneifolia Ten," Food Chemistry, vol. 112, no. 4, pp. 874-879, 2009.

[24] A. Thiantanawat, B. J. Long, and A. M. Brodie, "Signaling pathways of apoptosis activated by aromatase inhibitors and antiestrogens," Cancer Research, vol. 63, no. 22, pp. 8037-8050, 2003.

[25] X. Tong, S. Lin, M. Fujii, and D. Hou, "Echinocystic acid induces apoptosis in HL-60 cells through mitochondria-mediated death pathway," Cancer Letters, vol. 212, no. 1, pp. 21-32, 2004.

[26] A. D. Adler, F. R. Longo, J. D. Finarelli, J. Goldmacher, J. Assour, and L. Korsakoff, "A simplified synthesis for mesotetraphenylporphin," Journal of Organic Chemistry, vol. 32, no. 2, p. 476, 1967.

[27] E. V. Motorina and T. N. Lomova, "Formation of supramolecular complex between imidazole and dichloro(5,10,15,20-tetraphenylporphinato)zirconium(IV)," Russian Journal of General Chemistry, vol. 80, no. 4, pp. 842-848, 2010.

[28] Y. Lu, J. Tung, J. Chen et al., "Salicylate exchange in mesotetraphenylporphyrinato salicylato thallium (III), Tl (tpp) (2$\mathrm{OH}-\mathrm{C}_{6} \mathrm{H}_{4} \mathrm{CO}_{2}$ ) and ${ }^{13} \mathrm{C}$ NMR investigation of its homolog 
thiocyanato (meso-tetra-p-tolyl-porphyrinato)thallium (III), Tl (tptp) (SCN)," Polyhedron, vol. 18, no. 1-2, pp. 145-150, 1999.

[29] E. Fagadar-Cosma, D. Vlascici, and G. Fagadar-Cosma, "Monomer and sandwich type dimmer complexes of $\mathrm{Zr}$ (IV) with meso-tetraphenylporphyrin. Synthesis and comparative IR, UV-vis and HPLC behavior," in Proceedings of the 12th Symposium on Analytical and Environmental Problems, Szeged, pp. 2529, Szeged, Hungary, September 2005.

[30] Z. Sun, Y. She, Y. Zhou, X. Song, and K. Li, "Synthesis, characterization and spectral properties of substituted tetraphenylporphyrin iron chloride complexes," Molecules, vol. 16, no. 4, pp. 2960-2970, 2011.

[31] D. Vlascici, O. Bizerea-Spiridon, and E. Fagadar-Cosma, "Metalloporphyrin based fluoride-selective Electrode," in Proceedings of the 13th Symposium on Analytical and Environmental Problems, pp. 92-95, Szeged, Hungary, September 2006.

[32] L. Jiang, L. Gao, and Y. Liu, "Adsorption of salicylic acid, 5sulfosalicylic acid and Tiron at the alumina-water interface," Colloids and Surfaces A, vol. 211, no. 2-3, pp. 165-172, 2002.

[33] E. C. Yost, M. I. Tejedor-Tejedor, and M. A. Anderson, "In situ CIR-FTIR characterization of salicylate complexes at the Goethite/Aqueous solution interface," Environmental Science and Technology, vol. 24, no. 6, pp. 822-828, 1990.

[34] L. Yang, Y. Xu, Y. Su et al., "FT-IR spectroscopic study on the variations of molecular structures of some carboxyl acids induced by free electron laser," Spectrochimica Acta A, vol. 62, no. 1-5, pp. 1209-1215, 2005.

[35] G. Knör and A. Strasser, "Coexisting intraligand fluorescence and phosphorescence of hafnium(IV) and thorium(IV) porphyrin complexes in solution," Inorganic Chemistry Communications, vol. 5, no. 11, pp. 993-995, 2002.

[36] B. J. Pistorio and D. G. Nocera, "Photochemistry of group IV porphyrin halides," Journal of Photochemistry and Photobiology $A$, vol. 162, no. 2-3, pp. 563-567, 2004.

[37] I. N. Tret'yakova, V. Y. Chernii, L. A. Tomachinskaya, and S. V. Volkov, "Physicochemical properties of novel mixedligand complexes of zirconium and hafnium bis(4-benzoyl-3methyl-1-phenyl-2-pyrazolin-5-onato)phthalocyaninates," Theoretical and Experimental Chemistry, vol. 42, no. 3, pp. 175-180, 2006.

[38] L. A. Tomachinskaya, Y. Y. Kolotilova, V. Y. Chernii, and S. V. Volkov, "Electrochemical behavior of novel bis( $\beta$-diketonate)phthalocyanine complexes of $\mathrm{Zr}(\mathrm{IV})$ and $\mathrm{Hf}(\mathrm{IV})$," Theoretical and Experimental Chemistry, vol. 39, no. 2, pp. 104-108, 2003. 

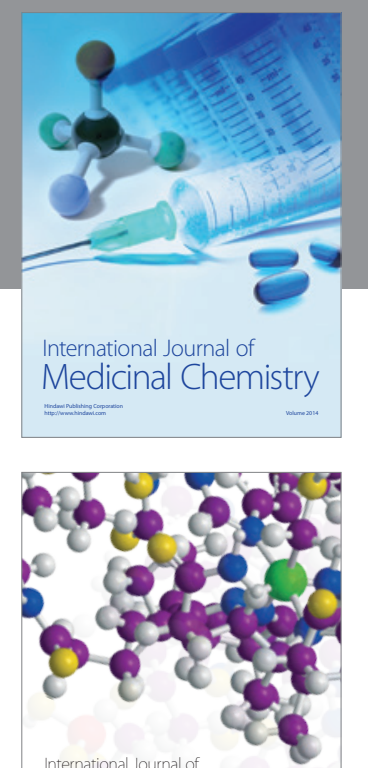

\section{Carbohydrate} Chemistry

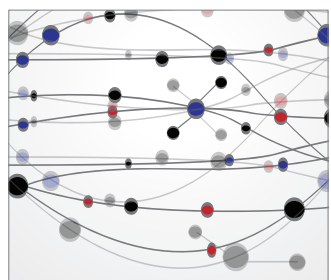

The Scientific World Journal
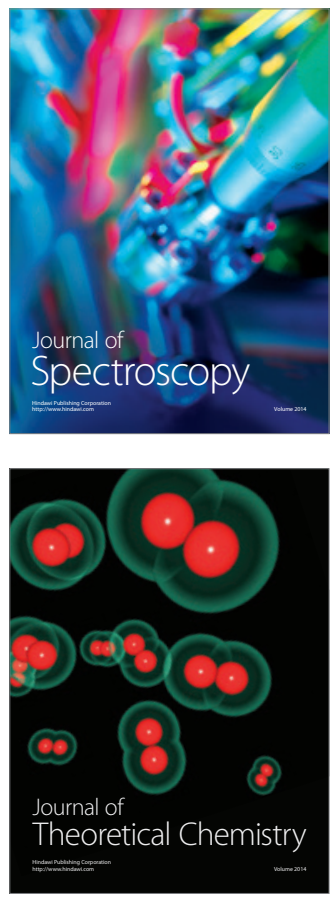
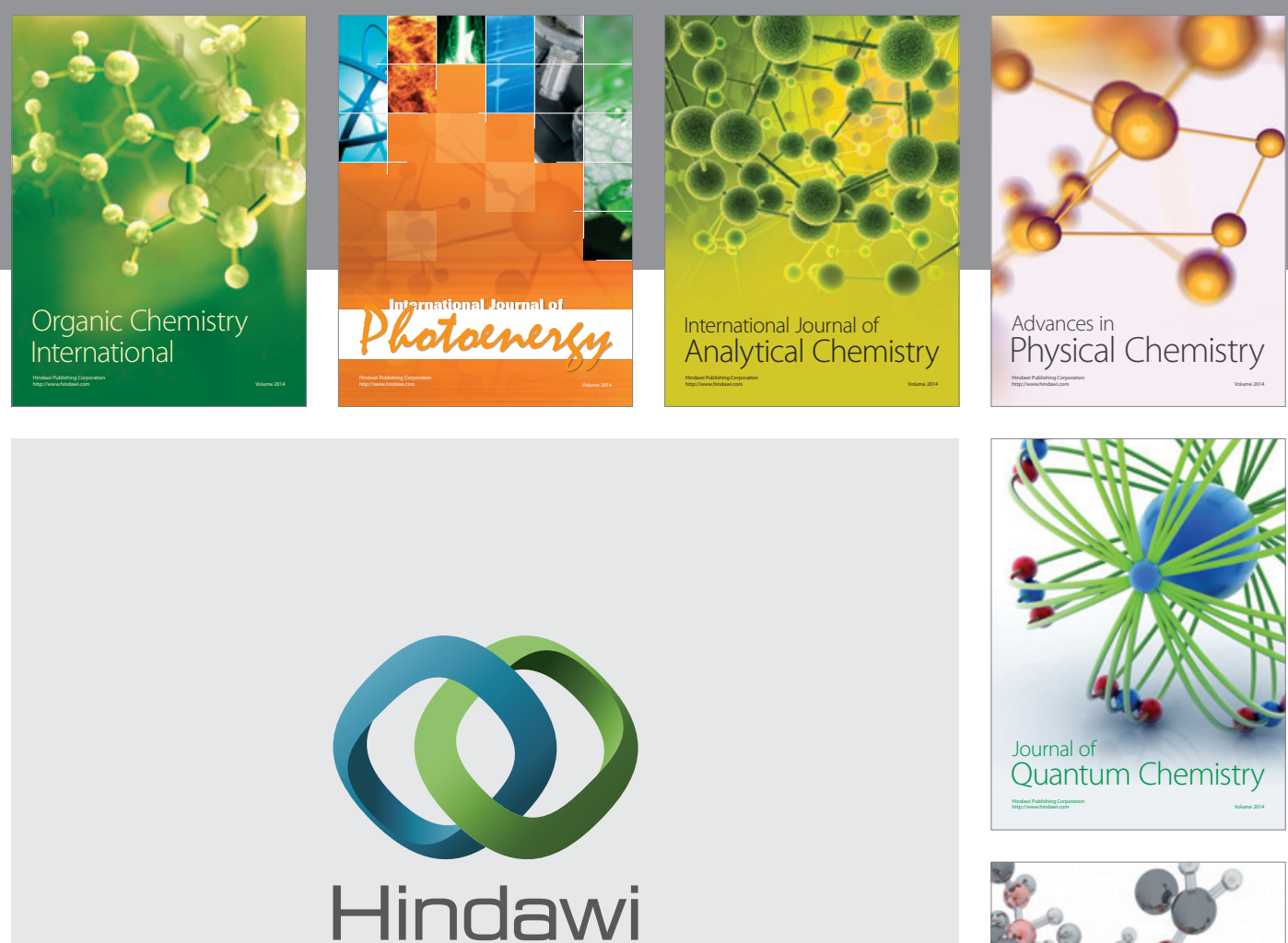

Submit your manuscripts at

http://www.hindawi.com

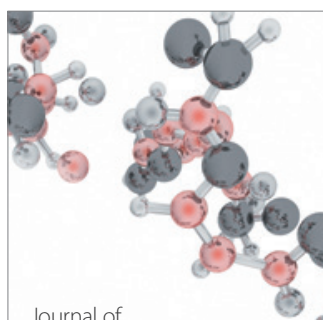

Analytical Methods

in Chemistry

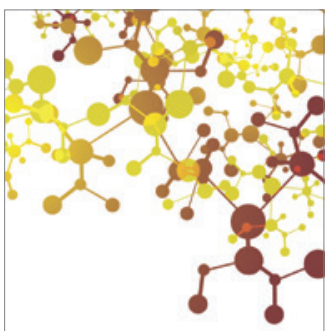

Journal of

Applied Chemistry

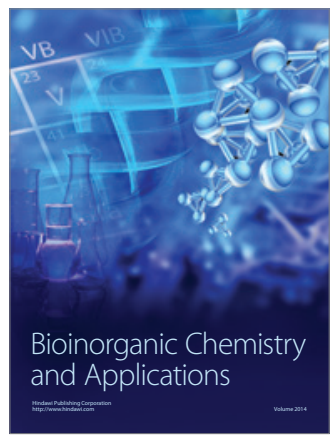

Inorganic Chemistry
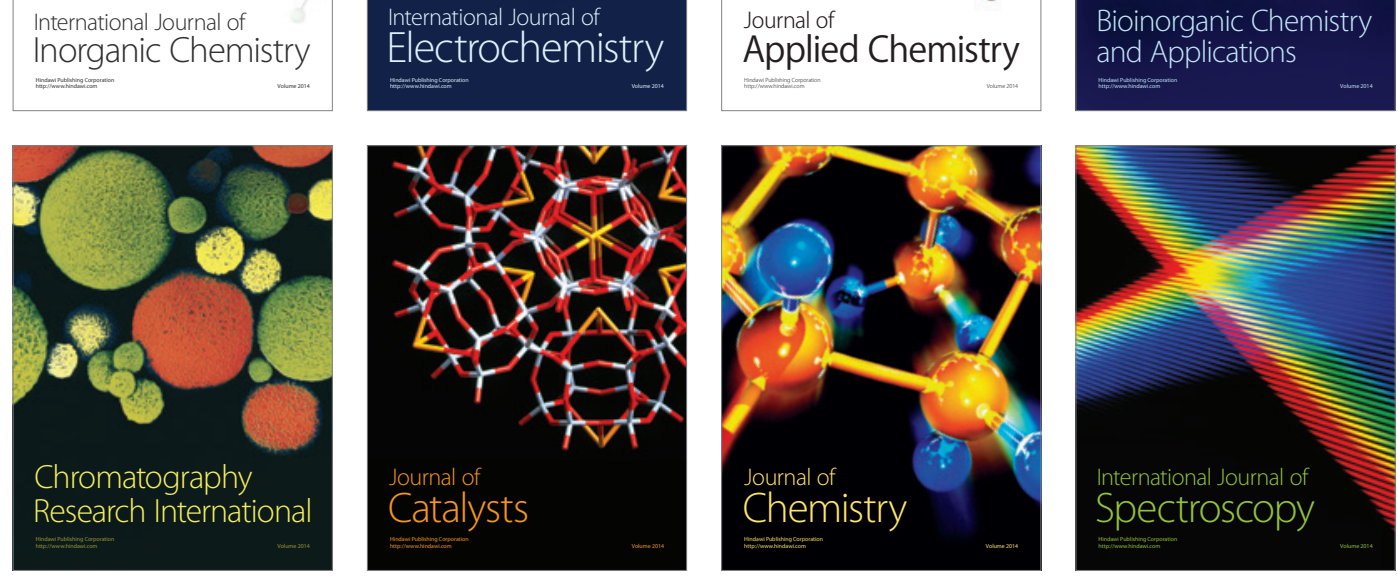